\title{
SDM
}
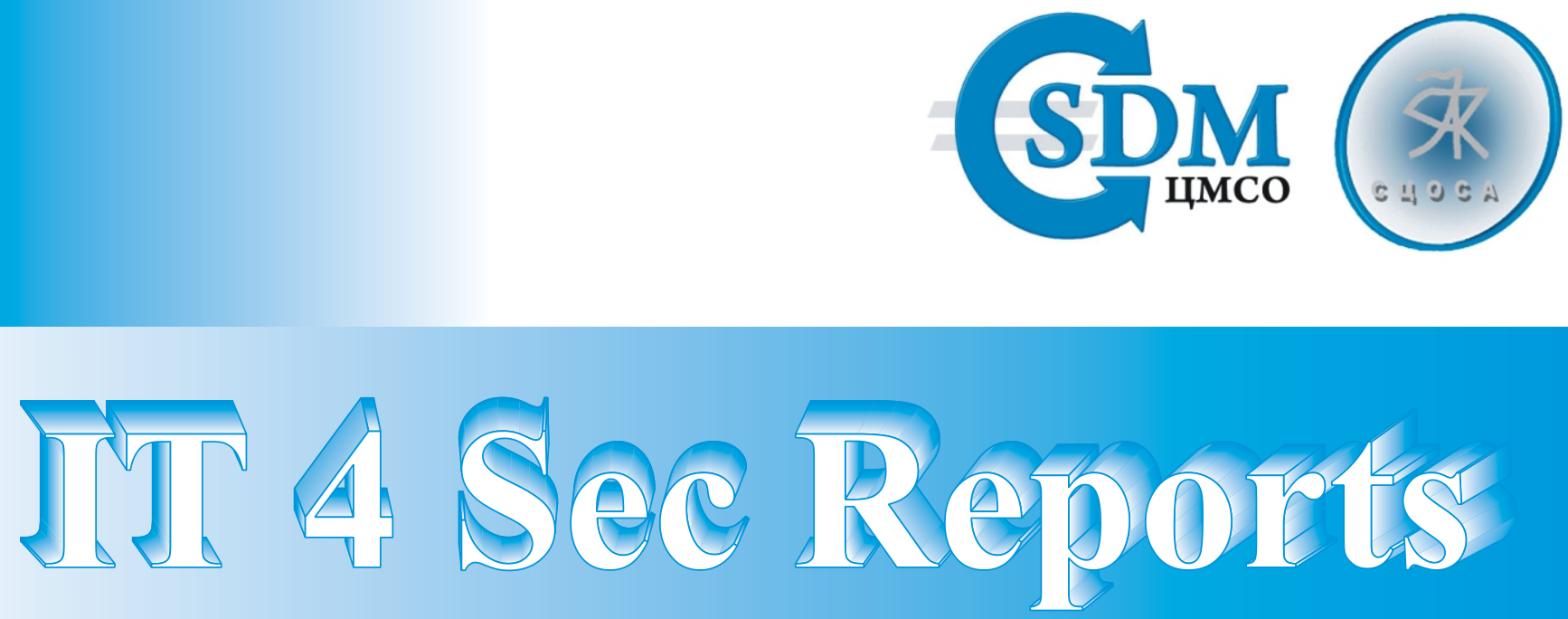

\section{Towards the Exploration of Future EU Roles as a Global Security Actor}

Valeri Ratchev Todor Tagarev Uwe Nerlich

Към изследването на бъдещи роли на ЕС като глобален играч в сферата на сигурността

Валери Рачев Тодор Тагарев Уве Нерлих 


\title{
IT4Sec Reports 92
}

\section{Towards the Exploration of Future EU Roles as a Global Security Actor}

\author{
Valeri Ratchev, Todor Tagarev and Uwe Nerlich
}

Institute of Information and Communication Technologies CSDM | Centre for Security and Defence Management WWW.IT4Sec.org 
Valeri Ratchev, Todor Tagarev and Uwe Nerlich, Towards the Exploration of Future EU Roles as a Global Security Actor, IT4Sec Reports 92 (Sofia: Centre for Security and Defence Management, December 2011).

IT4Sec Reports 92 is an internal deliverable within the FOCUS project summarising the input by CSDM and CESS (Centre for European Security Strategies) to working package 6.1. It suggests a way to describe future EU roles as a global security actor. It then provides a comprehensive analysis of the principal trends in global security and identifies essential drivers of change, examining also specific challenges and strategic shocks that may steer global developments to one or another alternative future. Finally, it presents a framework for exploring EU global security roles, incorporating a concept of the global EU power and examination of the external-internal nexus in the EU Common Foreign and Security Policy.

IT4Sec Reports 92 представя основни изследователски резултати на ЦМСО и Центърът за европейски стратегии за сигурност (CESS) по работен пакет 6.1 на проект FOCUS. Предложен е начин за описание на бъдещи роли на EC в сферата на глобалната сигурност. Представен е задълбочен анализ на основни тенденции в глобалната сигурност. Идентифицирани са основни драйвери на промяната, както $и$ специфични предизвикателства и възможни стратегически шокове, които биха могли да насочат развитието към едно или друго алтернативно бъдеще. Представен е рамков подход за изследване на глобалната мощ на ЕС и връзката между външни и вътрешни развития в Общата външна политика и политика за сигурност на съюза.

Valeri Ratchev is Chief of the Cabinet of the Minister of Foreign Affairs of Bulgaria and Associate Senior Fellow of the Centre for Security and Defence Management, <www.IT4Sec.org/csdm>. He was Ambassador Extraordinary and Plenipotentiary of the Republic of Bulgaria to the Republic of Iraq (2005-2009) and served as Deputy Commandant of the 'G.S. Rakovski' Defence and Staff College and Dean of its National Security and Defence Faculty (2000-2005).

Todor Tagarev is Senior Researcher at the Institute of Information and Communication Technologies of the Bulgarian Academy of Sciences and Head of its IT for Security Department, $<$ www.IT4Sec.org > and Centre for Security and Defence Management, $<$ www.defencemanagement.org >, Editor-in-Chief of Information \& Security: An International Journal, <http://infosec.procon.bg > and the DCAF series in Security and Defence Management.

Uwe Nerlich is General Manager of the Centre for European Security Strategies (CESS), $<$ www.cess-net.eu>. He was Chairman of the European Study and Defence Analysis Group/ ESDAG (2003-2005), Senior Vice President of IABG and Director of the IABG Centre for European Strategy Research (1995-2002), and member of the Executive Board of the Stiftung Wissenschaft und Politik/SWP (1965-1995).

\section{Acknowledgement}

The research leading to these results has received funding from the European Union Seventh Framework Programme (FP7/2007-2013) under grant agreement $n^{\circ} 261633$. For more information visit the project website at http://www.focusproject.eu.

Original version, in English, 2011 


\section{CONTENTS}

EXECUTIVE SUMMARY ..............................................................................................

1. INTRODUCTION: FORESIGHTING EU ROLES IN A FLUID ENVIRONMENT......................... 7

1.1. Methodological instantiation of the FOCUS approach ........................................ 7

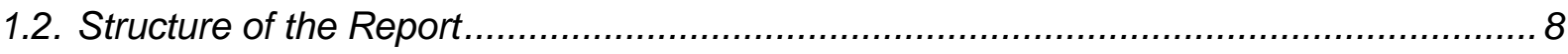

1.3. Embarking on a foresight exercise in a fluid environment....................................... 9

1.3.1. Major challenges in an uncertain environment ....................................... 9

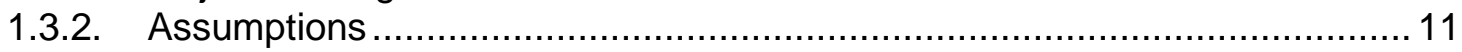

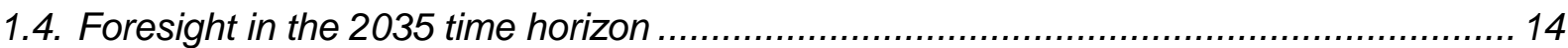

2. PROBLEM SPACE FOR ANALYZING EU ROLES AS A GLOBAL ACTOR BASED ON THE WIDER PETERSBERG TASKS ............................................... 17

2.1. Principal dimensions in the description of EU roles as a global Security Player ...........17

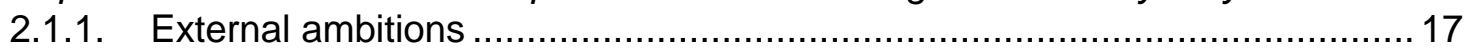

2.1.2. Comprehensiveness of EU power........................................................ 17

2.1.3. Cohesion of the European Union as a global security actor ....................... 18

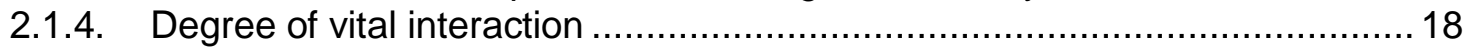

2.1.5. Nature of EU security mission and operations .......................................... 19

2.2. Exogenous threats and challenges to the EU.................................................... 19

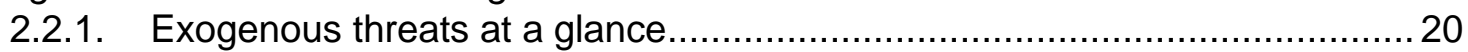

2.2.2. Mapping vulnerabilities of the EU and its citizens.................................... 22

2.2.3. Risk assessment concepts and methods ............................................... 25

2.3. Expected specific challenges for the EU global role in the perspective of $2035 \ldots \ldots \ldots . . .27$

2.4. Relevant Research Programmes ................................................................... 29

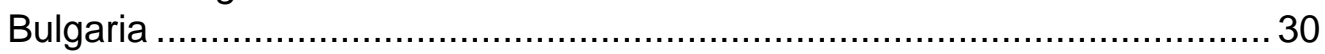

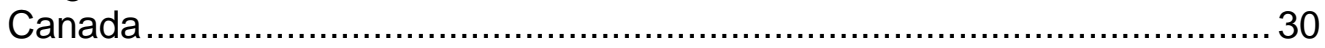

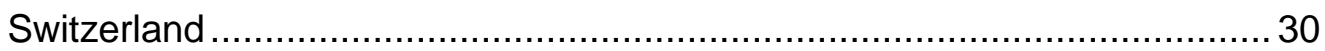

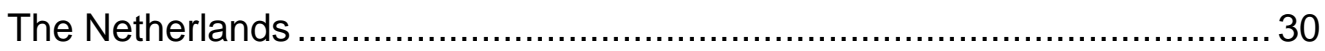

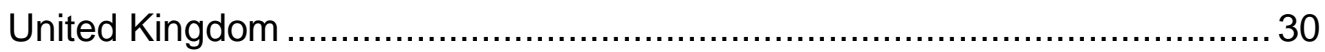

United States ................................................................................... 30

Initiatives at European level ............................................................ 31

Activities of interest in the framework of NATO ...................................... 32

United Nations ............................................................................. 32

2.5. Relevant methods for exploration of EU roles as a global security actor ..................... 33

3. TRENDS, DRIVERS AND POTENTIAL STRATEGIC SHOCKS............................................ 35

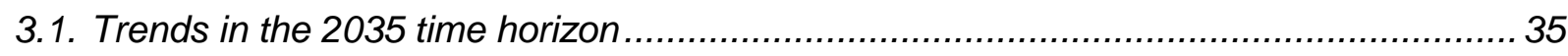

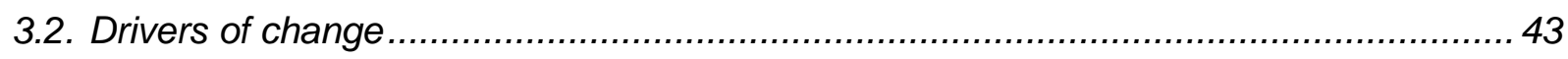

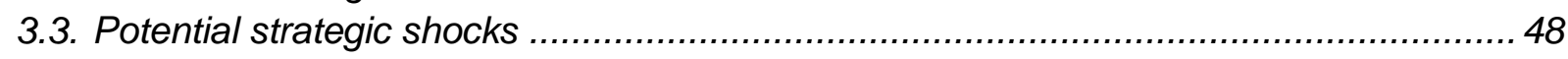

4. FRAMEWORK FOR EXPLORING EU GLOBAL SECURITY ROLES ...................................52

4.1. The external-internal nexus in the European foreign and security policy .....................53

4.2. The concept of the global EU power ................................................................. 56

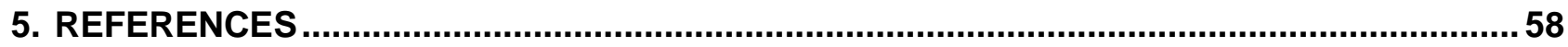




\section{List of Figures}

Figure 1: Population growth (in percentages), medium variant 38

Figure 2: Population aged 65+, medium variant (in percentages of total population). 39

Figure 3: Breakdown of likely energy sources 40

\section{List of Tables}

Table 1. Overview of security threats. 22

Table 2. Risk Levels Matrix and Interpretation. 26

Table 3. Estimated status of nuclear forces in 2011. 41 


\section{EXECUTIVE SUMMARY}

The international system in the 2035 time horizon will be rather different from the current one. It will be more heterogeneous and hybrid than can be anticipated by short-term extrapolation. The scope of change will depend mostly on developments in several main domains and the interplay between the external environment of the Member States and the European Union and their domestic social and political demands. Key among them will be the enhanced political, social, ideological and environmental impact of globalisation, counterbalanced by the influence of parallel processes of fragmentation.

Adding to that the persistent financial crisis and frequent related discussions among leaders of EU Member States, it becomes impossible to extrapolate current trends in EU involvement in global security and predict what would be the Union roles in two to three decades. One cannot predict even how the European Union will look like in that timeframe. A number of hypotheses and scenarios on the future of the EU were published during our study (cf. Leonard, 2011; Piris, forthcoming), bringing forward widely differing alternatives of the political and institutional framework in which decisions on 'widening' the Petersberg tasks will be made.

Nevertheless, the findings presented in this report and its annexes set the ground for rigorous exploration of future security roles of the European Union in the tradition of Peter Schwartz (1991), enhanced by accumulated results from recent studies. The study team adopted a top-down approach to presenting the problem space for exploration of future EU roles as a global security actor based on the Petersberg tasks. This approach provides for a structured description of the problem space, including elaboration of principal dimensions for presenting EU roles as global security player and sets a holistic framework for examination of threats and vulnerabilities assessment, EU decision-making, and conceptual considerations.

This report ${ }^{1}$ suggests a way to describe future EU roles as a global security actor. It then provides a comprehensive analysis of the principal trends in global security and identifies essential drivers of change, examining also specific challenges and strategic shocks that may steer global developments to one or another alternative future. ${ }^{2}$ Finally, it presents a framework for exploring EU global security roles, incorporating a concept of the global EU power and examination of the external-internal nexus in the EU Common Foreign and Security Policy.

The report is based on the understanding that the problem space description it provides naturally addresses a variety of aspects, including policies and capabilities of different kind. This problem space description provides an information background and indicative questions for subsequent FOCUS work. FOCUS foresight work will fully take place in the context of civil security research as defined in the 7th EU Framework Programme. Because FOCUS is not defined as a policy-related project, it will not further address policies, and as a civilian security research project, it will not perform foresight related to defence and military aspects of security.

1 FOCUS Deliverable 6.1 provides in addition an overview of the EU experience as a global security actor with a focus on the definition and the evolution of the understanding of what was once designated as Petersberg Tasks and offers an analysis of aspects of the Lisbon Treaty and the European Security Strategy relevant to the Common Foreign and Security Policy (CFSP).

2 For theme-specific definitions of terms like 'driver,' 'strategic shock' and others refer to Annex 1 to FOCUS Deliverable 6.1 and Todor Tagarev, Foresight-related Terminology in Defence, IT4Sec Reports 82 (April 2011). 
Additional information supporting the use of this report and follow up work in Work Package (WP) 6 and related 'Big Themes' of FOCUS is provided in nine annexes to deliverable 6.1 as follows:

WP6 specific definitions

Abbreviations used in the main text of the report

Evolution of the security and defence dimension of the European integration process

CSDP mission reports and analyses of operational experience

Research projects

Specialised publications, including articles, studies, and books

A list of dedicated web resources

Lists of organizations and experts

A catalogue of questions for scenario foresight

Thus, this deliverable serves a ground for scenario foresight. The consequent research in WP6.2 will identify distinct future roles of the EU as a global security actor, while WP6.3 will deliver the respective security research scenarios. 


\section{INTRODUCTION: FORESIGHTING EU ROLES IN A FLUID ENVIRONMENT}

This report presents an analysis of the problem space for exploring future EU roles as a global security actor. It is structured according to the Common Framework for FOCUS Problem Space Reports, as detailed in the project methodology. ${ }^{3}$ This is an internal deliverable produced by project partners CSDM and CESS as input to FOCUS WP6.1 Problem Space. It is intended to serve as input for WP6.2 "Scenarios for EU roles" and WP6.3 "Scenarios for security research," as well as for the identification of cross-cutting issues among the FOCUS five 'big themes.'

\subsection{METHODOLOGICAL INSTANTIATION OF THE FOCUS APPROACH}

FOCUS WP 6 explores alternative paths for EU in the global domain of security. In comparison with other 'big themes,' the WP 6 exploration is intrinsically more hypothetical, with few, if any, historical precedents. A global perspective is necessary if the EU is to be understood as a global actor. But at this stage of global affairs the world is at the brink of shifts that may bring fundamental restructuring in the international social system and its security domain. Their impact on the EU is both inevitable and profound. In reality, EU is a global actor in some areas of international relations but is rarely perceived as a global security actor.

Then the specific questions are:

1. Under what conditions would EU need to become a global security actor?

2. What will this involve? and

3. What will be the consequences for the EU and Europe if the Union fails to prepare for and act as a global security actor?

WP 6 thus requires primarily a top-down approach with a longer time horizon and a critically important need to specify exploratory scenarios.

In the implementation of such approach, WP 6.1 resulted in this report providing a structured description of the problem space. WP 6.2 will then identify distinct future roles of the EU as a global security actor. These roles may be alternative or complementary.

Each distinct role will be described through a set of values (choices) along each of the principal dimensions in the decision space.

EU roles will evolve, and new distinct roles will emerge under the impact of a set of drivers, trends, and, possibly, strategic shocks, or wild cards.

The exploration of the decision space is not random; it is guided (and in some sense constrained) by some overarching concepts on the global role of the EU and its evolution.

Threats and challenges, in their evolution, form one group of drivers, while the study of vulnerabilities of the European Union will serve primarily to enhance the understanding of transversal issues, e.g. how internal security developments affect the EU's choice of roles as a global actor, and vice versa.

3 For the full list of project deliverables see www.focusproject.eu. 
Hence, preparing the ground for WP 6.2 and WP 6.3 studies, this problem space report examines, inter alia, dimensions, drivers, trends, strategic shocks, threats, vulnerabilities, constraints and transversal issues.

WP 6.2 will then result in 'scenarios of EU roles' ('context scenarios') to meet the challenges described in the Problem Space Report. In particular, the exploration of the problem space of 'EU as a global actor based on wider Petersberg Tasks' will address new threats that have not been dealt with and could involve additional Petersberg Tasks. WP 6.3 then will deliver scenarios describing the exercise of alternative roles, i.e. how the EU might perform its roles in the future. These scenarios will be used to deduct security research requirements, hence 'security research scenarios,' and will serve in defining timelines and priorities. These scenarios will be embedded in the FOCUS methodology and platform, thus providing for the study of transversal issues and lending for future adaptation.

The analysis of the embedded scenarios will result in the definition of security research requirements. These requirements may stem from:

- the need to elaborate innovative strategies to resolve the issues described in the embedded scenario;

- the search for adequate concepts of operation, organisational arrangements and procedures for interaction among EU players and partners in the implementation of the comprehensive approach;

- definition of novel capability requirements, for which technologies do not yet exist;

- identified opportunities to achieve comparative advantages through spin-in, i.e. opportunities to adapt and integrate existing or emerging commercial technologies for security purposes, etc.

\subsection{STRUCTURE OF THE REPORT}

According to the FOCUS framework and the project methodology defined in D2.1, this report presents the necessary additional information to operationalise implementation, especially for use by the Future Groups. Chapter 2 structures the problem space for analyzing EU roles as a global actor based on the wider Petersberg tasks. It recommends principal dimensions for describing EU roles as a global security player, provides analysis of the structural conditions for EU decision-making, review of exogenous threats and challenges to the EU, the vulnerabilities of the Union and its citizens related to global security roles and applicable risk assessment, as well as risk assessment concepts and methods. It then outlines expected specific challenges for the EU global role in the perspective of 2035. The chapter presents also identified national, European and other programmes aiming to enhance capabilities to meet relevant exogenous challenges through research. Finally, it provides a brief overview of theme-specific methods for scenario foresight.

Chapter 3 is dedicated to theme specific trends and drivers that may lead to a particular context scenario and emergence of a new global security role of the European Union. It further provides a list of potential strategic shocks that may cause an abrupt change in evolutionary patterns. Chapter 4 elaborates on the framework for exploring EU global security roles.

Additional information is available in the annexes to FOCUS Deliverable 6.1 that provide theme specific definitions; abbreviations; description of the evolution of the security and defence dimension of the European integration process; CSDP mission reports and analyses of operational experience; relevant research projects; lists of specialised publications, including articles, studies, 
and books; a list of dedicated web resources; lists of organizations and experts; and a catalogue of questions for scenario foresight.

\subsection{EMBARKING ON A FORESIGHT EXERCISE IN A FLUID ENVIRONMENT}

The question is not about the EU having a global security role or not - the Union already has an internationally recognised role. As two of the futurists of Europe indicate, "the European Union, the world's leading economic power in 2009, could constitute an appropriate level of economic sovereignty within globalisation - the EU is too large to be ignored by any business, government or regional bloc in the world - but the historical conditions in which it emerged as a political entity and the institutional regime that ensued prevent it from assuming this role" (Fitoussi \& Laurent, 2009).

The focus of the study is not on how to project the EU achievements in the future but to facilitate the definition of plausible options describing the character and intensity of that role. Historically, the process of elaboration of a political entity as a global security actor has included several principal elements: the entity should have (or should be able to build) a significant expeditionary capacity, ability to generate political will for this capacity to be exploited on the global security scene, to engage in solving critical international security disputes, and to be recognised by the others as a decisive global actor. From the perspective of the EU such development requires also a strong and long lasting internal cohesion, an effective decision-making process, stable public support, and systematic efforts in building comprehensive operational capabilities.

The exploration of options however takes place in a fluid environment. For one, it is not clear which EU can be taken as a point of departure. The EU is not a given, but is currently in the centre of structural debates. Different EU models are needed to reflect different environmentspolitical, economic, and strategic -in different time frames to identify different global security roles. Already today the financial pressures, but implicitly also e.g. the Libyan experience call for changes. The EU has already moved beyond the Lisbon Treaty to what has become a 'Lisbon +' arrangement and, at the time of writing this report, EU leaders suggest further changes almost daily.

To reflect this environment, before reflecting on historical experience, the report starts with a review of the major challenges and hypotheses.

\subsubsection{Major challenges in an uncertain environment}

In the beginning of the second decade of the Twenty first century Europe is confronted with fundamental challenges. The more or less common sense throughout European societies is that financial crises, growing unemployment, and related social difficulties come as a result of poor political leadership, unacceptable withdrawal of states from politico-economic affairs, and inefficiencies at the European scale of politics. Obviously, the people feel that they do not have the capacity to overcome the surge of complexity in their life while national governments face fundamental problems in dealing with the interdependence and total competitiveness of the contemporary world. Europe as a whole is not secure (in comprehensive terms) and effective at home and has not got a relevant influence (to say nothing about dominance) in its strategic environment. 
One may see all these developments as collateral difficulties with a temporary effect. Others may evaluate them as tectonic and look at them as a turning point in the realisation of the European project. However, the current structural debate at EU level illustrates the way the political leadership is looking for opportunities to cope with the growing challenges. The EU is open for changes. Obviously, it is a political, but mostly an analytical challenge to generate illustrative hypotheses on how the future of Europe might look like and to discuss their relevance to the potential choices of EU roles as a global security actor. Such hypotheses are not yet scenarios, but if introduced, they will help steer the debate on the EU future in different environments (i.e. political, economic, and strategic) and in different timeframes in order to identify plausible alternative global security roles.

Investigating potential future roles of the European Union on the global security scene involves a discussion about leadership and choices. The aim of this study is not to affirm what is already known and knowable about EU as an actor in the security domain of international relations. Rather, it is to explore the many ways in which EU itself and the world as a whole could co-evolve in the future, and to examine what those possible alternative paths may imply for the EU security roles.

The role of the policy maker, whether in a domestic or an international system, is to master the system: to be able to take actions now which will lead to desirable events, or to avoid in the future undesirable events. Leadership and choices in the case of the EU's Common Foreign and Security Policy (CFSP) and the Common Security and Defence Policy (CSDP) are shared responsibility - shared between people, nations, states, and leaders. This imperative is at the core of the European project and will remain valid in future.

As discussed more fully in this FOCUS deliverable, the European leadership should make choices in fluid strategic environment in which the coming decades are premature with tectonic shifts in global distribution of power, world economic architecture, and regional geopolitics. Fluidity of the environment comes from still-to-be-discovered effects of globalisation and their impact on people mindsets, social constructs, market vitality, national politics, and international security architecture. The current analyses are mostly focused on the visible aspects of globalisation at the strategic level as production and market redistribution, financial power and stability, and the redistribution of power. They may produce the next generation of studies focusing on issues like social turbulence, political ideology and religion as defensive arms, decomposition of control over the power, the role of individualism, etc. The equilibrium between strategic and social impacts of globalisation presumably will determine the most significant security development in the next decades: the rising of regional powers and their search for global roles.

The future European leadership in security will make choices in an environment characterised by increased uncertainty and risk. Humanity has unprecedented opportunity to manage poverty, to balance political and ideological differences, and to find new purposes for cooperation and collaboration - goals that form the backbone of the CFSP paradigm. However, the lack of progress in dealing with these issues may produce further distress within the EU immediate environment and on the global scene. As the studies of security aspects of globalisation unequivocally state, the main characteristic of globalisation is the simultaneous growth of the forces of integration and fragmentation.

Both integration and fragmentation have their benefits and costs. Integration and fragmentation will shape the world developments in the coming decades with consequences that can hardly be predicted. The European Union itself is not secure from infiltration of negative influences. The forces of integration such as business, finance, technology, anti-poverty, care for the planet, and others are actually changing the world. They have their internal contradictions, 
such as the ongoing relocation of jobs from developed to developing countries, establishment of the so called technologically super-empowered groups and individuals, supply chain vulnerabilities, environmental costs, and the rising prospect of health pandemics; the EU as a global actor is expected to cope with the ensuing challenges. The forces of fragmentation are rooted in nationalism maintaining the status quo, ambitious geopolitics, ethno-religious radicalism, and demographic disproportions (Institute for the Study of Diplomacy, 2008). Then there is a widespread understanding that today there is a stark and disturbing contrast between the growing integration of global economies and the fragmented, dysfunctional global politics (former British Prime-minister Tony Blair repeatedly spoke on the issue).

Before embarking on foresight the future global role of the EU, the FOCUS study will address what by now already is a disturbing controversy: Which EU do we assume as a point of departure and what are the structural options and what is the time frame? The EU is not locked for changes. The Treaty of Lisbon has created a new external action system for the EU, but not a new external common policy (Missiroli, 2010). This is obvious because one of the challenges the postLisbon EU has to cope with is its status on the international stage. The Treaty can be seen as 'a work in progress,' and its effectiveness depends both on the political will to pursue a common threat perception and positions and the capacity of the EU empowered leadership to build and maintain consolidated CFSP and CSDP. This is because the EU treaties have promised a lot but the sphere of foreign and security policy is still predominantly intergovernmental, without Member States (MS) foregoing sovereignty. In this environment decisions on CFSP are often made as a sum of Member States foreign policy interests and ambitions. Fitoussi \& Laurent (2009) illustrate such frustration, arguing that the EU presents in itself 'a little globalisation.' And this hypothesis is currently in the centre of structural and functional debates. FOCUS will go beyond this notion to relate different hypotheses on future EU constructs to alternative future environments (at least in political, economic, and strategic aspects) in different time frames to identify options for different global security roles. ${ }^{4}$

\subsubsection{Assumptions}

\subsubsection{The world}

Within the time horizon of 2035 we may expect two virtual periods of development in the global security domain. During the next ten to fifteen years the momentum still inspired by the end of the Cold War and the wave of globalisation will shape the world political, economic, and security affairs. Divergence is the core characteristic of that period. Its defining features are accelerated redistribution of economic power towards Asia, changing regional dynamics in the Middle East and the turbulence within the global West. Most of the foresight studies (Möckli, 2011; Strategic Trends Programme, 2010; National Intelligence Council, 2010) concur that the process of redistribution of economic power, combined with the West's increased lack of resources and political will to unilaterally provide global stability, will result in a security vacuum. It is also obvious that during this time segment neither China nor India would be able to step into the shoes of the US as a global security dominant. Experts expect as well a gradual transformation of the growing economic potential of the emerging powers into regional geopolitics with ambitions to influence and control. In such perspective the FOCUS research will provide reading on the key trends that may lead to different pictures of future conflicts as explained in 4.1 of this report, suggesting as well a set of adequate EU security roles that will reflect the transversal impact of structural and deterministic drivers and trends.

4 A list of possible constructs is presented in the next section of this report. 
Referring to the period after 2020-25, we will need to look beyond the space in which current trends could be extrapolated. The main feature of the political world in that timeframe will most probably be the absence of poles and the advent of multiple regional powers and nongovernmental actors. The world is likely to be more "... interdependent, complex and unstable" (Gnesotto \& Grevi, 2006). A 'non-polar world' is a world dominated not by one, two or even several powerful states, but rather a conglomerate of many states and non-state actors, each of which will have some capacity to influence global affairs. This means a tectonic shift that counters the trend of the past three centuries, or even longer.

Further, the exploration of possible EU security roles has to account for those hidden factors that are currently at the peak of their impact, such as globalisation, or about to grow quickly in importance, e.g. the spread of advanced technologies. For instance, several years ago experts identified a tendency of slowing down globalisation; three key parameters have been used - transboarder trade, flow of private capitals, and movement of people. With slowing trade, reduced capital mobility and fewer people crossing borders, three key elements of globalisation have been reversed. At the same time, the spread of advanced technologies with multiple applications-from healthcare to deadly combat, from ground to space, and from material to virtual-has the potential to grow quickly. The future security environment will be shaped also by efforts to eradicate extreme poverty; according to UN estimates around 2020 less than 10 percent of the world population will be classified as extremely poor.

FOCUS will study those plausible developments that may lead to alternative futures in a dynamic way, looking for gradual accumulation of arguments relevant to potential EU security missions, operations, and capabilities.

\subsubsection{The European Union}

The global view portrayed in the preceding sub-chapter may serve as a platform for analyzing different hypotheses on the EU future. A significant number of reports analyse specific aspects of future developments in Europe and the EU such as climate, water, land, transportation, etc. Eight of them were identified and examined. They were written between 1999 and 2011 and discuss the future of the EU overall construct in the time period between 2010 and 2040. Most of them are titled as scenarios or alternative futures but indeed the methodology of scenario building has been applied with considerable limitations and interpretations. Following the approach of The United States Commission on National Security/21st Century (1999), it is important to distinguish descriptive from prescriptive works, not to let the pressure of current concerns generate unwitting bias and selectivity, as well as to avoid any compartmentalisation on subject matters. Nevertheless, even when written as essays, they bring important intellectual light on the future of the European project.

Focusing on EU structural perspectives, and not limiting analysis to current institutional difficulties, the following hypotheses have been selected as most relevant to the specific theme:

- The first hypothesis one could title as 'implementation model.' It is based on projection of Lisbon Treaty legal and decision-making framework and implementation mechanism to find, or actually waiting for, incremental solutions to hitherto unresolved problems within the institutional system, but without the capacities to deal with challenges from the international environment (Leonard, 2011; Gnessoto, 2006). It assumes a combination of internal flexibility within the Lisbon Treaty frame and highly stable and predictable international environment in the long-run. Both preconditions are tested by recent developments as the financial crisis and the turmoil in North Africa and the Middle East. 
- The second hypothesis one could call 'reconstruction model.' It is focussed on finding selective solutions within the Lisbon Treaty system, e.g. a smaller Euro zone with more integration. It could be realised in a relatively short-term, but would affect the EU at large (Leonard, 2011). As Laursen (2009) put it: "Flexibility, multi-speed integration, in various forms, have contributed to the integration process in the past, so why not in other areas, including CFSP?" Instrument like Schengen, Eurozone, Eurocorps, etc., have been established as products of flexibility within the treaties. The agreement, reached by the leaders of France and United Kingdom (November 2010) to increase their cooperation in security and defence illustrates another opportunity for variable geometry and speed of integration. The development of external dimensions in several domains could reinforce such a development, e.g. in addition to finance, energy, migration, and communication.

- A third hypothesis that is already under discussion is to keep the Lisbon-27 system, but establish a more integrated smaller system based on new treaties, possibly as a political or fiscal union (Leonard, 2011; Ellis, 2001). One could title this option as a 'fence model because the goal here seems simple - to ring-fence the stronger nations within a tight union in order to contain the crisis. As it was publicly discussed (Reuters, 28 November 2011) one approach is based on a smaller group of EU states that would agree on stricter fiscal discipline, allowing others to join if they agreed to abide by the same principals. Another option is to have an agreement just between Germany and France, with others joining later.

- The fourth hypothesis envisages an intergovernmental treaty system outside the scope of the Lisbon system which would call for more integration in critical domains like defence and security. Marc Leonard (2010) titled this as "Federalism without the federalists," while Fitoussi \& Laurent (2009) prefer 'Europe of public goods.' The context of this hypothesis is that institutionally the EU may evolve through reconciling two fundamental realities of the European project - the nation state and pooled sovereignty. Actually, this pseudo-federal system will focus on political and social goods like macroeconomic stability, employment, advancement of knowledge, communications, environmental protection, mobility, energy to be delivered between all Europeans and not only one or other member state (Fitoussi \& Laurent, 2009).

The distinctions between these models need more refined discussion, which is already happening on the political arena and under the pressure of the financial crisis. Their focus is on the relation between the all Member States and the subset of those that are able and willing to move towards deeper integration; re-nationalisation and marginalisation of the $\mathrm{EU}$ in case of failing integration efforts have also been spelled out.

The study will further discuss these models in relation to potential EU roles as a global security actor based on the wider Petersberg Tasks. For that purpose the following inter-related conceptual issues would need a theoretical clarification and illustration:

- Europe as a collective action system;

- The regional and global structures/environments the European action system is operating within;

- The role(s) of the European action system as a global security player; and

- The time frame within which the European action system is assumed to play what role within which environments. 
These four issues provide a conceptual framework that allows treating each of the FOCUS five 'big themes' in a systematic way. The study will investigate which of the models is relevant to particular environment in what time horizon and what roles the EU may assume as a global security actor.

\subsection{FORESIGHT IN THE 2035 TIME HORIZON}

In building and sustaining its global role, the EU has to find solutions to serious conceptual, normative, organisational, and capability issues. Holistic and long-term thinking should be a European foreign and security imperative. The main problem with this approach comes from the fact that mere extrapolation of current trends within the security domain is not applicable. Globalisation-indisputably the driving force for the coming decades-is a highly dynamic, complex phenomenon that is very susceptible and may take different shapes under any among a significant number of plausible shocks.

Remoteness of decisions over time defines the need for enduring policy planning that should be based on foresight scenarios. In case of a considerable distance in a time perspective an appropriate method for policy planning is to create a set of foresight scenarios with contextual or alternative future character. The foresight scenarios are broad views of how the future might turn out. They are intended as tools for forward planning, rather than as predictions of what the future world will be like. Explaining the space of plausible futures in which the future world may unfold the EU global security role should be tied not to particular scenarios but to the space sketched by the scenarios.

In line with the theory of Peter Schwartz (1991), the process begins by identifying forces of change in the world, and then combines those forces in different ways to create a set of diverse stories-or scenarios-about how the future could evolve. Importantly, scenarios are not predictions. Rather, they are thoughtful hypotheses that allow us to imagine, and then to rehearse different strategies for how to become better prepared for the future; or more ambitiously - how to help shape better futures ourselves.

The anticipated global role of the EU should be determined in a way adequate to global developments. In this line of reasoning the framework of the role, described by the Petersberg tasks, should be seen mostly as a starting point, mainly for the purpose of planning the necessary operational capabilities.

An important element of dealing with fluid environment is introduction of a system of horizons of the EU's role as a global actor. Selected for this project time horizon of year 2035 is dictated by the specific objective to plan the necessary security research as an intellectual support for the policy of establishing an EU global role. Looking ahead to the next decade the EU will obviously focus on the remedying the consequences of the financial crisis and implementing the necessary legislative and organisational changes to make such situations, if not impossible, at least reliably controlled. During this period the EU will most likely be limited to the existing role, and will use the available operational capabilities to implement the Petersberg Tasks. The focus of planning will be put on better packaging of military and civilian components, their technological development and functional maintenance.

The EU will likely seek to enter the next stage of its development with a clear idea as to the architecture and norms, as well for its own role in global security relations. In a multipolar but interrelated world, the EU will likely seek an important role in coping with the hottest international security issues. Since most likely during this period the system of international relations will be 
virtually unrecognizable from 2011 point of view, the Petersberg Tasks will probably be specified based on lessons learned. The package of operational capabilities is expected to rely less on the military instrument.

The international system in the 2035 time horizon will be rather different from the current one "owing to the rise of emerging powers, a globalizing economy, an historic transfer of relative wealth and economic power from West to East, and the growing influence of non-state actors" (National Intelligence Council, 2008). It will be more heterogeneous and hybrid than can be anticipated by short-term extrapolation. The scope of change will depend mostly on developments in several main domains and the interplay between the external environment of the countries and the Union and their domestic social and political demands. Key among them will be the strong political, social, ideological and environmental impact of globalisation.

It is safe to assume that in the coming couple of decades the world as a whole and most countries will experience the impact-positive or negative-of globalised economic relations. This will have, despite all others, a major effect on social balances and will drive societies towards specific political demands regarding national and international security. These may produce a new balancing between public attitudes and relevant political will, between alignment and selfprotection, or between international engagement and isolation.

After waves of crises, globalised economic forces will deeply affect all other domains of world affairs: ideologies and beliefs and their political impact on governance, the global order and geopolitical ambitions that will drive the political behaviour of states, the spread of weapon systems and technologies that may permit transformation of economic power into ambitions for control, environmental developments and their impact on all other domains.

In the horizon of $2035 \mathrm{EU}$ will probably seek to achieve full internal consolidation in order to realize its capacity of a comprehensive global power. The focus will be on the restructuring of the system of international relations in a manner consistent with the settled redistribution of power. The EU can be expected to seek global roles, supported by a new generation of capabilities and implemented within a new network of genuine strategic partnerships.

We expect the concept of security in the time horizon of 2035 to move further away from narrowly defined 'defence+,' through a 'spectrum of security,' towards societal and human security that will generate significantly different conceptual views. One may expect that security will continue to derive from national power, but at the same time nations will neither resemble what they did a century ago, nor will power have the same well-known dimensions.

Globalization of economy and politics inevitably will lead towards globalisation of geopolitics. Geopolitics is about control of geographical space. In the coming decades the space will differ profoundly from what is known now. The wide spread of technologies, knowledge, skills, and services will build a new geographic domain. Globalised business will be much more powerful than governments in most of the developing areas of the world. It will create different social environments across borders, producing new roles for politics and politicians. In parallel, a new notion of security will gradually win recognition.

In such an environment the range of security challenges will grow with new kinds of threats, which will arise in new areas of the international-national security realm, and thus will significantly widen the spectrum of conflict. But even with such expectations, war as it is known today will be of lesser concern. The principal issues of 'military nature' such as strategic parity will be focused on space and global communications, surveillance and navigation grids, for example. 
Consequently, the list of international security actors will undergo significant change. Within the transition from 'national' to 'international' and 'global,' the core problem, with which the theory and practice of security should cope with, will be the constitution of the security actors and the subjects of security. As a result, both the security agencies and policies that use them as instruments have to be reconsidered and redesigned.

In such an environment, the elaboration of a consolidated concept of global security, in which EU specific roles may occur, would seem a serious research challenge. Even further, solving the conceptual problem of global security probably will require auxiliary elaboration of the theory of international relations - meaning that any post-liberal framing of security should overcome the limitations of state centrism and determine the character of 'global' in the security domain and the transition to it from 'international' and 'national.' As some researchers anticipate, the paradigm of security may be transformed into 'management of insecurity' in an environment of an unmanageable number of subjects and objects of security (Stedman, Jones \& Pascual, 2008; Peake, Scheve \& Hills, 2007). 


\section{PROBLEM SPACE FOR ANALYZING EU ROLES AS A GLOBAL ACTOR BASED ON THE WIDER PETERSBERG TASKS}

\subsection{PRINCIPAL DIMENSIONS IN THE DESCRIPTION OF EU ROLES AS A GLOBAL SECURITY PLAYER}

Several options for describing systematically potential future roles of the EU as a global actor were analysed. Five dimensions are recommended to describe such roles in the horizon of 2035 in follow up FOCUS work - external ambitions; comprehensiveness of EU power; cohesion of the European Union as a global security actor; degree of vital interaction; and nature of EU security mission and operations. Each of these principal dimensions is presented in detail below.

\subsubsection{External ambitions}

External ambitions will characterise eventual EU roles from the point of view of effective influence and engagement at the global scene. It is a multiple and complex dimension that integrates political will and physical capabilities, reflects EU internal cohesion and external relations and illustrates the interdependence between changing power structure and global 'interconnectedness.'

Possible 'values' along this dimension may vary largely depending on which of the above mentioned characteristics dominates. As an illustration, the following 'values' may be considered, starting from the least to the most ambitious:

- No expeditionary roles, i.e. EU will be mainly and most of all focused on defending its territory within a reactive rather than projective role;

- EU policy of containment in which EU acts as a regional power, capable effectively to influence its 'immediate neighbourhood' environment in a comprehensive and sustainable manner;

- EU acting as a well armed regional policeman able to conduct high-intensity humanitarian interventions (such as the one in Libya in 2011);

- 'Global reach' through projection of sufficient and sustainable power to permit decisive engagement in preventing or solving problems, vital for EU and the global order. Such power projection may involve multiple capabilities, e.g. political, economic, military, informational, financial, and cultural. It could be exercised independently or with strategic allies or partners. The latter case defines specific requirements to 'interoperability' in a broad sense, including compatible political values, shared threat perception, doctrine, technical, etc.

\subsubsection{Comprehensiveness of EU power}

This dimension characterises EU future roles from instrumental point of view. It illustrates how wide the spectrum of EU capabilities might be, how comprehensive could be its 'comprehensive approach' indeed, while performing any type of global role, and where the EU will place its priorities.

As an illustration, the instruments of EU global roles may include as minimum the following: 
- Security instruments like peace enforcement and peacekeeping, with significant contribution of 'justice \& law enforcement' capabilities or 'the big stick' capabilities permitting to explore influence through hardcore military capabilities, intelligence, early warning systems, etc.;

- Financial instruments in order to influence economic developments globally while providing or controlling access to credits and hard currency;

- Technological, productivity enhancing, and transportation instruments in order to maintain a leading role in the most advanced areas of global economy;

- Knowledge in modern governance and social engineering in order to be able to provide culturally sensitive support for the enhancement of good governance and institution building, including in security and defence sectors.

- Civil society and cultural instruments like NGOs, public information, media, social networks, arts, and artists able to enhance and strengthen the other elements of the EU global role.

\subsubsection{Cohesion of the European Union as a global security actor}

This dimension illustrates the internal political and social ability to meet the requirements of any type of a global role. It reflects both the level of actual concentration of power within the Union's governing bodies and the ability-and willingness-of nation states and societies to delegate to the European Commission such power. As an illustration, possible 'values' along this dimension may include as minimum the following:

Decline in coordination of foreign, security and defence policies and return to a statecentric model, with selective common approaches on ad-hoc basis;

Preservation of the 'current status' seen not so much as an instrument for exploring global role but as a compromise;

EU developing as a security actor at two (or more) tiers, e.g. integration in selected functional areas and/or among a number of EU countries (cf. Piris, forthcoming); ${ }^{5}$

Enhanced security and defence integration in terms of production and building security capabilities simultaneously with "communitarisation" of funding for security missions;

Single European intervention forces for the full spectrum of 'wider Petersberg tasks.'

\subsubsection{Degree of vital interaction}

The degree of vital interactions illustrates the ability of EU to have, generate and maintain allies and partners, while exploring its global role. It comes from the expectation that the EU's own internal capabilities, cohesion, and 'communitarisation' of instruments would not be sufficient to define an essential global role. The core of this idea is that any EU global role is possible as the Union is engaged in stable and sustainable interactions within the Western community and with

5 This book was not yet available by the time this report was written. For the main ideas see "EU architect calls for two-speed union," Financial Times, 3 November 2011; and Jean-Claude Piris, "The future of Europe: towards a two-speed European Union," E!Sharp, December 2011, http://esharp.eu/essay/2-thefuture-of-europe-towards-a-two-speed-european-union. 
other strategic actors. As an illustration, possible 'values' along this dimension would include the following as a minimum:

- Weakening Western integration and poor international co-operation;

- EU role as change-agent within a new world order;

- Deepening Western integration and selective international co-operation;

- Deepening Western integration and comprehensive international cooperation;

- Global actors 'concert' (all work smoothly together) for achieving the Millennium Development Goals.

\subsubsection{Nature of EU security mission and operations}

The nature of EU global security mission is determined mainly by how its roles are defined and the set of operations potentially applicable to a variety of security related scenarios. They should be understood on the basis of the Petersberg Tasks and the Lisbon Treaty.

The 'wider Petersberg Tasks' are not yet clearly defined or operationalised, while no respective planning decisions have been taken so far. The Lisbon Treaty as well does not elaborate in depth on independent global security roles for the EU.

Addressing such shortcomings, the European Defence Agency concluded in its long-term vision report of October 2006 that "ESDP operations will be expeditionary, multinational and multiinstrument, directed at achieving security and stability more than 'victory.' Information will be critical, whether informing the 'war of ideas' in cyberspace, or facilitating effective command decisions. 'Asymmetry' will apply not merely to an opponent's tactics but also to his aims and values. In such circumstances, the military will be only one of a range of instruments applied to achieve the campaign goals" (European Defence Agency, 2006).

To identify the future nature of EU security missions and operations it is necessary to determine those Petersberg Tasks which have potential global dimensions and to consider them not as a basis for planning but, as originally intended, to outline the scope of autonomous actions (widely understood, i.e. implementing the comprehensive approach) with global relevance.

\subsection{EXOGENOUS THREATS AND CHALLENGES TO THE EU}

This section of the report presents current views on global and international exogenous threats and challenges EU has to cope with applying the Petersberg Tasks and instruments, as well as concepts and methods of risk assessment, along with the limitations in applying them in planning security measures.

It starts with admitting that Europe is in crisis. Divergence is significant at both national and continental level delineating the borders between the stable core and heavily indebted southern periphery. Political differences at the Brussels scene on 8-9 December 2011 have reached their peak with the opposition by the UK to the common approach to resolve the debt crisis. A new intergovernmental treaty would set tighter budget rules and strengthen economic coordination as means of tackling the debt crisis and restoring market confidence. And this is the most important element in the overall security problématique because the outcome remains unclear. It affects both 
Member States and the Union. The problem is the study cannot entirely rule out differentiation on a regional basis, an Europe on two or more speed, or a new monetary union.

In this situation structural and non-structural aspects of the EU pose unique challenges resulting from the interactive overlapping dimensions between exogenous and indigenous threats. One thing is obvious: the financial crisis and its consequences represent the most serious current threat to the European Union and its Member States and on their background any other threat is seen as marginal. It is obvious also that the recovery will take time during which the EU will have very limited opportunities to invest into and to explore its global role in the security domain.

\subsubsection{Exogenous threats at a glance}

The exogenous threats to Europe are already clearly explained by the European Security Strategy (ESS) (2003). The elaboration of this document without doubt is one of the most exciting, but certainly also one of the most important projects the EU has undertaken in the broad field of foreign and security policy. The Strategy not only fills a gap within the conceptualisation of the Union's common policies and provides a focus for CFSP and CSDP, but also establishes a ground for a long term vision on planning and programming the development of capabilities.

The ESS is based on the recognition that "large-scale aggression against any Member State is now improbable," and on the concept of comprehensive security. From this ground the document emphasises five 'key threats,' all of which are closely interconnected. Sven Biscop (2004) describes them in the following way:

- Terrorism, for which "Europe is both a target and a base"; the Strategy notes that terrorism "arises out of complex causes," including "the pressures of modernization, cultural, social and political crises, and the alienation of young people living in foreign societies";

- Proliferation of WMD - "potentially the greatest threat to our security"; in "the most frightening scenario" WMD could fall in the hands if terrorists;

- Regional conflicts, both worldwide and at the borders of the EU, which "impact on European interests directly and indirectly" and which "can lead to extremism, terrorism and state failure";

- State failure, which "undermines global governance, and adds to regional instability" and which "can be associated with obvious threats, such as organized crime or terrorism";

- Organized crime, an internal threat with "an important external dimension," such as "cross-border trafficking in drugs, women, illegal migrants and weapons" as well as gemstones and timber; organized crime "can have links with terrorism" and is "often associated with weak or failing states."

Obviously, terrorism and proliferation of WMD are treated as the most important direct threats to the EU under the presumption that any large-scale aggression is no longer probable. Accepting those threats as direct is based on the presumption that the Member States, not the EU, may be targeted by terrorists groups. So despite its external dimension, terrorism is viewed mainly as a threat to the state. The threat would indeed be increased if a terrorist group were to acquire WMD. The US State department and experts raise an alarm that it is just a matter of time for this to happen; nevertheless, the only parties that currently do possess WMD are states. The jihadist 
terror is losing ground and should be perceived as a manageable risk rather than a strategic threat to the European soil.

Rather than terrorism or WMD, the most important threat emerging from the new security environment seems to be the growing social frustration that is rising up within those countries that have failed to cope with challenges of globalisation. In the Middle East and North Africa the public turmoil erupted mainly because globalisation and new information and communication channels exposed the inability of the corrupted and criminalised authoritarian regimes to govern effectively and to provide social security that was typical for the regimes during the Cold war.

The ESS does not elaborate much on the conflict regions where destabilisation and civil wars may bring serious migration waves to Europe. The Western Balkans, South Caucasus and the Mediterranean continue to generate internal tensions with possible European impact. As the enlargement process is in 'a strategic pause' and the ability of the Union and the Member States to provide political attention and resources to countries in those areas, the number of conflicting incidents are growing, for example in Kosovo.

Organised crime is again both an external and an internal threat. Its most serious impact is on new Member States that are still working to consolidate their security institutions in order to be able to cope with complex criminal threats. In a shaky financial environment, transnational criminal networks are among the highest threats to the stability of countries that are struggling to stabilise banks and markets.

In conclusion, the European Security Strategy is an important and valuable instrument both for building a common threat perception and supporting long term planning. It does not provide all necessary answers that come from the new European security environment and perspective though. Nevertheless, it provides a solid point of departure for further EU efforts to enhance CFSP and CSDP.

In addition to this official statement, academic analyses explain in detail threats in the comprehensive security domain that may put European and Member States interests at risk. Table 1 provides a list of such threats.

Such environment will make the cooperation rationale relevant in the coming decades. It will affect the EU decision-making on CSFP, as well as the development of respective capabilities. In this context, Petersberg tasks are currently placed on a fragile economic, political and social platform. Though only some of these vulnerabilities are directly relevant to Petersberg tasks, most can be interpreted as pre-conditions for exercising these tasks. Since current national governance frameworks will be unable to keep pace with looming global challenges unless extensive reforms are implemented, the EU should first address these challenges. Increasingly, emerging economies feel that they do not have sufficient influence in international institutions as currently designed, seeing this as unfair. Yet there is uncertainty over the ability and willingness of rising powers to shoulder a greater share of global responsibilities, as well as reluctance on the part of established powers to recognize the limits of their own power. Petersberg tasks' current relevance is within an evolving balance among these trends. 
Table 1. Overview of security threats.

\section{Economic threats}

Asset price collapse

Extreme commodity price volatility

Extreme consumer price volatility

Extreme energy price volatility

Fiscal crises

Global imbalances and currency volatility

Infrastructure fragility

Liquidity/credit crunch

Regulatory failures

Retrenchment from globalization

Slowing Chinese economy (as a risk from EU point of view)

\section{Environmental threats}

Air pollution

Biodiversity loss

Climate change

Earthquakes and volcanic eruptions

Flooding

Ocean governance

Storms and cyclones

Societal threats

Chronic diseases

Demographic challenges

Economic disparity

Food security

Infectious diseases

Migration

Water security

\section{Geopolitical threats}

Corruption

Fragile states

Geopolitical conflict

Global governance failures

Illicit trade

Organized crime

Space security

Terrorism

Weapons of mass destruction

\section{Technological threats}

Critical information infrastructure breakdown

Online data and information security

Threats from new technologies

\subsubsection{Mapping vulnerabilities of the EU and its citizens}

The section of report outlines vulnerabilities of the EU and its citizens that could be associated with a global security role and implementation of the comprehensive approach. The purpose of mapping vulnerabilities is to improve the understanding and the awareness of asymmetric dependencies, as well as relevant communications about threats. Thus, the EU and its citizens may better be informed about those values that may be at risk while implementing a global security role and applying a comprehensive approach in Petersberg-type operations. As a method, it is also relevant to the responsibility of decision-makers to see where resources are most needed and what kind of capabilities are required for collective protection and defence.

Most security studies are focused on vulnerabilities related to hazards and industrial catastrophes, climate change, critical chains of supply (as energy) as well as for the purposes of the critical infrastructure protection (cf. MOVE, 2011; World Energy Council, 2008; Metzger, 2005). 
The understanding of vulnerabilities related to the global scene of security is not so advanced. The recent EU experience in this context is mainly within the US-driven 'global war on terror' and the number of peace support operations in which the Union has been engaged. More complex is the record of the Member States, especially those that have contributed to the operations in Kosovo, Afghanistan, Iraq, and Libya. FOCUS will pay special attention to this issue analysing EU experience and the experience of Member States and other actors in an effort to provide thorough and well argued map of eventual vulnerabilities of the EU and its citizens.

The mapping of vulnerabilities related to implementation of Petersberg Tasks will account for the character of the role, the EU performance, and the complex internal preparedness to meet the consequences of being globally engaged in security affairs. It is also a function of the capacity of the opposing sides to react directly or in an asymmetric manner and to cause physical, material, financial, and psychological damages. At the level of assumptions the following elements of the vulnerability map may be considered from the perspective of EU global security roles and Petersberg Tasks:

- EU and its citizens will become increasingly vulnerable to attacks on their own soil

Such vulnerability will result from an active global role aiming to shape the strategic environment, almost certainly alongside US and other traditional allies. It will be most probable during the first half of the time horizon of this study when the capacity of the West to impose its political, economic and security influence will continue to dominate the world scene. States, hybrid forces, terrorists, and other groups under pressure will acquire different types of weapons, possibly including weapons of mass destruction, and some may attempt to use them. Eventual further decline in the military preparedness of EU and Member States may serve as a catalyst for such ambitions. In this case vulnerabilities may result from the gap between the intensity and scale of the self imposed role (where the comprehensive approach may not require use of dominant military power) and the internal ability to meet a disruptive reaction (where military capabilities are essential).

- Vulnerability may increase as a result of strategic 'asymmetric dependence'

Europe exists within the historical centre of the world's geopolitical space. Despite the end of the Cold war its geopolitical context is a particularly difficult. It is surrounded by Russia and a large arc of lasting instability starting with Western Sahara, passing the Middle East, and including Central Asia. In this environment, there are a few stable and democratic countries, many others in a process of transition, matured autocracies, and unpredictable rogue tyrannies. Demographic pressure from these countries is growing. Most sources of strategic raw materials and emerging markets for European goods are behind the arc of instability. Nuclear proliferation is closer to Europe than to any other major power. So far, US and Europe have a coordinated approach to the threat of proliferation. But this factor may fade in importance, not just as American power recedes from Europe under massive budgetary pressures, but because Europe is no longer central to Washington' security. In the future, a situation may occur, in which a regional crisis may involve a European country and while this may be a local tragedy, American security will not be dramatically influenced. This 'asymmetric dependence' is a strategic problem that has rational solutions. But if not managed properly, it may lead to an increase in European security vulnerability.

- EU and its citizens will be increasingly affected by transitional processes at the European strategic neighbourhood

Transitional processes in North Africa, the Middle East, the Persian Gulf, and Central Asia will continue in a mixture of opportunities for democratic development and threats to regional 
stability. If, as it is expected, such transition takes years, than the EU and Member States will become vulnerable to a complex of political, social, economic and internal security issues. On one hand, they will arise of the necessity of being directly engaged (including the 'responsibility to protect') with comprehensive packages, for a relatively long time, and as a leading actor. On the other, the EU and Member States have to cope with certain consequences like meeting a significant to mass migration. Unavoidably this will affect the social cohesion of European societies, especially in large urban areas. As the experience of the last couple of decade shows, such situations usually lead to a deepening gap between CFSP ambitions at the EU level and their public support at national level.

- Vulnerability will enhance as result of increasingly porous borders

Any global engagement-being collective or of a Member State, peace-making or humanitarian, military or anti-terrorist-puts national borders under pressure. Certainly, the comprehensive approach is designed to cope exactly with such challenges. However, many countries will have difficulties keeping threats out of national soil and their governments will be politically committed to uphold borders' integrity. Presumably, this will be causa perduta as no border can be protected against a combination of unhesitating migrants, communication abilities, transportation flexibility and free flow of money. Taking into account that borders are most porous to the spread of religious and ethnic 'great ideas' makes the scale of borders vulnerability clearer.

- Global security roles will require more engagements in foreign crises

As mentioned earlier, the global role needs effective actions in crisis prevention and response. Interstate wars probably will continue to occur at least during the first half of the study period, but most conflicts will be of internal nature. Even now it is very difficult to find any internal conflict that, after passing through a civil war stage, has been completely and sustainably resolved. Engagements will require more resources, multiple-including more specific-capabilities, political will and considerable public support. Moreover, any military engagement, and even a good part of the supply of raw materials could become reasons of asymmetric response by religiously or ethnically motivated radicals and terrorists. The experience in Afghanistan and Iraq shows that this happened despite comprehensive programmes for stability and reconstruction. So, the balance sheet between global role ambitions and their practical value could put the cohesion within the Union under severe test and would certainly make national political environments very vulnerable.

- Space will become a critical and competitive environment

In the long-term perspective the US-Russian hegemony in the space may come to an end. Several other powers are investing systematically in civilian, military, communication, and intelligence space-based capabilities. The biggest threat to Western superiority would be the ability of any adversary power to destroy or block its space-based communications, navigation, surveillance and intelligence grid.

- Vulnerability of the MS and the Europeans will be under stronger influenced of global economic shifts

Global economic changes in the coming decades will produce both opportunities and difficulties. The expected picture is a combination of sustainable economic growth and uneven development, of integration into transnational business giants and fragmentation, of personal advance and failed societies. As a result of the spread of technologies (even not hi-tech), many nations and governments will face problems to provide qualified labour to materialize the benefits of new technologies and know-how. For many countries this may lead to a situation of being simultaneously wealthier and less secure. 
- Vulnerability from EU asymmetric dependence on foreign energy sources

Within the time horizon of the study growth and energy will be profoundly connected. Energy will preserve its strategic importance as the core of geopolitics and geo-strategy, including of emerging powers. The European dependence of external sources of energy will grow further, especially if stronger limitations on the use of nuclear power are introduced. Such perspective creates an environment of asymmetric dependence of Europe.

\subsubsection{Risk assessment concepts and methods}

The concept of 'risk' is defined as an arrangement of the 'impact' (summary of the expected results and effects) and 'likelihood' (a forecast about the occurrence) (Bergmans, et al., 2009). As this approach is applicable mainly for threat assessment, Nancy Renfroe and Joseph Smith (2011) have elaborated an additional dimension - vulnerability assessment. This two works are illustrative enough for clarification of the mechanism of risk assessment.

Then in or outside the object assessed occurs a matter which, if not handled on time, could become a threat for the object itself. The escalation can emerge as politically, socially, and naturally motivated process or as one related to productivity, i.e. the escalation can be directed, uncontrolled but gradual or sudden and incidental.

The level of risk for the object depends on the dimensions of threat and its vulnerability regarding the specific forms of threat. These particular dimensions basically include scope, intensity, decisiveness, durability and the ability to cause secondary effects.

The level of vulnerability also depends on the type of the object - social or physical, and is identified after the assessment of the threat.

The question of vulnerability of social systems in the broader sense of security is very complex and deals with vulnerability of populations, territory, critical infrastructure, urban areas, ecological systems, social stability (including ethnical and religious matters) etc. So the concrete impact criteria depend on the purpose of threat assessment.

This definition of risk delivers a precondition for taking countermeasures. Countermeasures are subdivided into measures taken to counter the threat once it reaches the object (in stopping, reducing or blocking the escalation) and actions taken to reduce the vulnerability of the object. The countermeasures do not always relate to the risk assessment because the security of the object, especially when it comes to a social object (different from a physical one, e.g. a building), is a question of a subjective estimation, called perceived threat (i.e. different leaders, governments and nations perceive one and the same threat in different ways).

The whole process described above applies both to long-term planning and to introducing mechanisms for immediate reaction. In the former case the risk assessment is based on scenarios; in the latter - it is based of concrete data.

Within the frame of these considerations, a risk assessment approach proposed by Renfroe and Smith (2011) has been adapted for the needs of theme specific analyses.

The EU common 'assets' (in terms of people, territory, interests, policies, facilities, freedoms) face a certain level of risk associated with various threats. These threats may be a result of natural events, industrial accidents, terrorist or intentional acts aiming to cause harm. 
Regardless of the nature of the threat, the presumption is that EU has a responsibility to limit or manage risks from these threats to the extent possible through risk management.

The first step in risk management is threat assessment. A threat assessment considers the full spectrum of threats for a given common value or interest. The assessment should examine supporting information to evaluate the likelihood of occurrence for each threat. For natural threats such as floods, fire, or earthquakes historical data regarding frequency of occurrence can be used to determine the credibility of a given threat. For terrorist and international threats however the likelihood of occurrence in given space and time cannot be quantified statistically.

Once credible threats are identified, a vulnerability assessment must be performed. The vulnerability assessment considers the potential impact of the loss from a successful attack in a broad sense of this term. Impact of loss is the degree to which the core functions of the EU are impaired by the given threat. A key component of vulnerability assessment is to properly define the ratings for impact of loss and vulnerability. These definitions may vary greatly from case to case. $A$ sample set of definitions for impact of loss may be developed through follow up research, e.g. considering terms like 'devastating,' 'severe,' 'noticeable' and 'minor.'

Vulnerability is defined as a combination of the attractiveness of EU 'assets' as a target and the level of deterrence provided by existing countermeasures. Various definitions can be used to rate vulnerability, e.g. 'very high,' 'high,' 'moderate' and 'low.'

A combination of the impact of loss rating and the vulnerability rating can be used to evaluate the potential risk to EU 'assets.' A sample risk matrix is depicted in Table 2. High risks are designated by red, moderate risks by yellow, and low risks by green.

Table 2. Risk Levels Matrix and Interpretation.

\begin{tabular}{|l|l|l|l|l|l|}
\hline & \multicolumn{2}{|c|}{ Vulnerability to Threat } & \multicolumn{1}{c|}{ Interpretation of the risk ratings } \\
\hline $\begin{array}{c}\text { Impact of } \\
\text { Loss }\end{array}$ & Very High & High & Moderate & Low & \\
\hline Devastating & & & & $\begin{array}{l}\text { These risks are high. Countermeasures } \\
\text { recommended to mitigate these risks } \\
\text { should be implemented as soon as } \\
\text { possible }\end{array}$ \\
\hline Severe & & & & & $\begin{array}{l}\text { These risks are moderate. } \\
\text { Countermeasure implementation should } \\
\text { be planned in the near future }\end{array}$ \\
\hline Noticeable & & & & & $\begin{array}{l}\text { These risks are low. Implementation of } \\
\text { countermeasure will enhance security, but } \\
\text { is less urgent }\end{array}$ \\
\hline Minor & & & & & \\
\hline
\end{tabular}


Further research work should identify appropriate criteria for rating losses and vulnerabilities having the EU as an object of security. ${ }^{6}$

Based on the assessment a risk diagram should be constructed. It illustrates the specific risk environment (conditions) for decision making in regard to planning and implementation of the EU global security role. In EU context, risk environment refers to what was noted as EU key assets: people, inviolable territory, common values, freedom of having sovereign Common Foreign and Security Policy and Common Security and Defence Policy, and safe and secure critical infrastructure.

Such risk management approach is finding ever wider application in security policy and strategy making, as well as in decision-making on investments in security measures and capabilities. For example, the approach is rigorously implemented by the US Department of Homeland Security since 2005 (Department of Homeland Security, 2005), by The Netherlands (Rademaker, 2009) and others.

Nevertheless, catastrophes such as the Fukushima nuclear disaster point clearly to the limitations of risk analysis, both in estimating likelihood and its explanatory power (Hagmann, 2011). These limitations become even more profound in attempts to address future security roles and missions, when often we have, at best, just a few precedents. Therefore any attempt at estimating probabilities or likelihood would be arbitrary and highly subjective. The alternative approach-and the one undertaken within the FOCUS project-is the foresight based on exploratory scenarios.

\subsection{EXPECTED SPECIFIC CHALLENGES FOR THE EU GLOBAL ROLE IN THE PERSPECTIVE OF 2035}

The chosen time span covers nearly a quarter of a century. The global political, economic, strategic and natural environment and the critical infrastructures on which societies will depend are certain to be different from today's and, more importantly, different from today's expectations and guiding objectives. This is especially true for Europe and its global role: Its dependencies on external powers, markets and raw materials, its exposure to unstable populations and unlikely prosperity in neighbouring populations and the uncertainties that beset the EU's social and economic stability and political coherence as well as the dynamics of global power structures render current previews at least as uncertain as respective expectations were some 25 years ago. Yet security research should be able to reduce uncertainties. FOCUS results are intended to support European security research during the next Five-year Security Research Programme (SRP) and results from the next SRP should support EU security decision-making in the subsequent 15 years: 2035 seems an arbitrary date. But the span is only a few EU and national terms away from $2020-2035$.

Theoretically the CSDP sector has finalité, described by the Article 42 of the consolidated Treaty of the European Union, which states:

1. The common security and defence policy shall be an integral part of the common foreign and security policy. It shall provide the Union with an operational capacity drawing on civilian and military assets. The Union may use them on missions outside the Union for peace-keeping, conflict prevention and strengthening international security in accordance

6 Directive 114/2008 Critical Infrastructure Protection already provides an example of an EU wide approach. 
with the principles of the United Nations Charter. The performance of these tasks shall be undertaken using capabilities provided by the Member States.

2. The common security and defence policy shall include the progressive framing of a common Union defence policy. This will lead to a common defence, when the European Council, acting unanimously, so decides. It shall in that case recommend to the Member States the adoption of such a decision in accordance with their respective constitutional requirements.

However, as a result of the insufficient achievements in the security and defence policy domain the $\mathrm{EU}$ is in a perennial process of change for as long as it serves the purposes of its members. In a world of potentially increasing global changes, if not turmoil, it will be pivotal for the EU that its development is guided by a concept of its global role that is shared by sufficient collective shaping power within its membership. Such concepts will increasingly require more of a long-term orientation for ongoing processes. The Initial Long-Term Vision report for European Defence Capability and Capacity Needs provided by the European Defence Agency (2006) was an ambitious and inspiring exercise in comprehensive capability planning, but is still a beginning without follow-up.

Such concepts for a global security role for the EU will require that its security posture (strategic orientation plus capabilities) and its internal structures for collective decision-making match. The Petersberg Tasks do not so far provide a sufficient base, although they have been incorporated into the Lisbon Treaty. They have never so far been the basis for decisions that define global roles for the EU. The upper level is critical for the EU's global role, but it has never been specified except for two widely different general interpretations: It does not rule out any military activities vs. it includes all military activities below the level of NATO responsibilities which in turn are also open to discussion, in particular in the longer run.

The Petersberg Tasks were originally intended to guide conventional force planning, and they are relevant to the extent the EU's conventional force planning has become a reality. They do not constitute a global security role. Widening the Petersberg Tasks would need to address roles with global consequences and it would need to address future strategic challenges that are different from traditional and in particular conventional capabilities toward which the EU can be exposed within the 2035 time horizon or in the longer run:

Capabilities that can impact from any distance (advanced drones, other advanced robotics systems, strategic cyber capabilities, space capabilities etc.);

Capabilities that can disrupt external EU lifelines (energy, communication, rare earth materials etc.);

Changing economic and financial leverage that can have negative or positive impacts on security challenges to the EU, as the First Annual Report on the Implementation of the EU Internal Security Strategy rightly observes (European Commission, 2011);

Challenges that result from differentials within the EU's environment/wider neighbourhood (population, age, employment, competence etc.).

Depending on the type of challenge the distinction between internal and external security differs: It gets blurred in all four categories of challenges: For the first category it does not exist except in case of outdated definitions of responsibilities. For the other three it will depend on how the internal structure and how the political, strategic, economic etc. environment develops. It will be applicable in the longer run in minor exogenous crises and in case of internal insecurity.

Given the EU's current economic clout and prevailing coalitions, any state of the EU can trigger security consequences on a global scale: 
- Disintegration or failure to develop internal structures in line with emerging challenges will have negative impacts - with repercussions on the EU;

- Confining the EU's security role to 'islandised' or mere neighbourhood-solutions would tend to marginalize the EU, but it would still tend to have global security consequences (emerging vacuum, changing coalitions, changing strategic dependencies). As in the first category the EU's viability would be at stake;

- In the division of labour from the Cold War it is theoretically still conceivable that the EU stay focused on non-military challenges and is protected by NATO or some substitute with US involvement;

- A more active regional security role within some agreed regional division of labour could have consequences for global security, e.g. in the Middle East and North Africa. But at this stage the EU's posture as a security actor would not suffice except in case of supporting coalitions with the US and/or strong regional allies. It would require a degree of strategic competitiveness;

- The EU could build up capabilities to become a coalition partner in major crises that could make the difference;

- It could do the same-depending on the global strategic environment-as a strategic balancer between global competitions;

- Even in the longer run it remains doubtful whether the EU will acquire the capabilities and strategic orientation as an autonomous power as envisaged prior to the ESDP.

Subsequent scenario foresight and analysis will serve to weigh these potential global roles in the 2035 perspective chosen. Each will also depend on how the EU's internal structures for collective security decision-making will develop. As Kishore Mahbubani (2009), one of the wisest observers of global security has warned, "many in the rest of the world are astonished that EU leaders and officials spend so much of their time on their internal arrangements when most of their emerging challenges are coming from external sources. A deep structural flaw has developed in the EU decision-making processes. Virtually no EU leader dares to suggest that the EU should spend more time looking outside rather than inside the EU." What this boils down to is that a global role for Europe would require more than a strategic posture to secure survival in front of major challenges, but the ability, will and resources to shape a sustainable global order to minimize external risks. In fact this is closer to Europe's 'genius,' but without a supporting capacity for global security roles this is not likely to be identified by the foresight work.

\subsection{RELEVANT RESEARCH PROGRAMMES}

This section of the report looks into national and European research programmes aimed to enhance policy making vis-à-vis relevant exogenous challenges and to support the development of respective capabilities. It also refers to several activities of potential interest, conducted in the framework of the United Nations and NATO with considerable involvement of European researchers. Since only a few are designated as 'programmes,' the section covers multi-year projects as well as known sequences of smaller projects.

The following were identified during the WP6.1 research ${ }^{7}$ :

7 National programmes are presented in alphabetical order. 


\section{Bulgaria}

- A series of studies to create, adapt and support the introduction of foresight-based planning in security and defence, conducted by what currently is Centre for Security and Defence Management at the Institute of Information and Communication Technologies - Bulgarian Academy of Sciences.

\section{Canada}

- Canadian Army 2040, Defence Research and Development Canada

\section{Switzerland}

- The International Relations and Security Network, coordinated by the Centre for Security Studies at ETH Zurich regularly addresses fundamental structural changes in the world considered unique in terms of scope, reach and complexity. It covers the subject under three broad narratives:

- Structural factors (geopolitical, institutional, normative, economic, technological);

- Shifting power dynamics;

- Implications.

\section{The Netherlands}

- A series of four foresight studies in support of security policy making, including the National Security Strategy, were conducted recently with the Cabinet or a designated ministry as lead sponsor;

- The Comprehensive Security research programme of the Hague Centre for Strategic Studies; 23 reports have been published in it framework by the end of 2011 .

\section{United Kingdom}

Strategic Trends Programme, Development, Concepts and Doctrine Centre, Ministry of Defence, publishing regular foresight reports under the title "Global Strategic Trends."

\section{United States}

The Global Trends series of the National Intelligence Council.

Strategic reviews and visions of the US Defense Department (Quadrennial Defense Review, National Defense Strategy, National Military Strategy, Transformation of War, etc.).

Global trends and the formulation of US Foreign policy studies of the US State Department.

The comprehensive studies on America's security challenges conducted by RAND Corporation, etc. 


\section{Initiatives at European level ${ }^{8}$}

Reports and publications in the area of "Justice, Freedom and Security," European Parliament;

Grant programme of the European Commission in the area of External relations and foreign affairs covering the following topics:

Common Foreign Security Policy;

Cooperation;

Development;

Enlargement;

External trade;

Foreign policies;

Humanitarian aid;

An Initial Long-Term Vision for European Defence Capability and Capacity Needs, European Defence Agency;

European Union Institute for Security Studies conducts research and regularly publishes study reports on the following relevant themes:

EU Foreign Policy;

Common Security and Defence Policy;

Disarmament;

Global governance;

ISIS Europe-a Brussels based independent research and advisory organisationmaintains a database on CSDP and EU missions and "CSDP Mission Analysis Partnership." In addition, it runs the following programmes:

Responding to Conflict and Crisis Management;

Gender and Security;

The European Council on Foreign Relations (ECFR) has three research programmes of potential relevance:

Wider Europe;

China;

Middle East and North Africa.

Since 2010 ECFR publishes a "European Foreign Policy Scorecard" - an innovative project that "will provide a systematic annual assessment of Europe's performance in dealing with the rest of the world"

8 Relevant projects implemented within the EU security research programme are included in Annex 5 to FOCUS Deliverable 6.1, www.focusproject.eu/web/focus/downloads/-/document_library_display/ 1QpQ/view/15032. 


\section{Activities of interest in the framework of NATO}

Allied Command Transformation:

Multiple Futures Project: Navigating towards 2030

Long Term Requirements Study (LTRS)

RTO System Analysis and Studies Panel

SAS-096, Key Performance Indicators in Measuring Military Outputs

SAS-094, Analytical Support to the Development and Experimentation of NLW Concepts of Operation and Employment

SAS-093, Risk-Based Planning

SAS-091, Allied Information Sharing Capability

SAS-090, Cost Efficiency Implications of International Cooperation

SAS-089, Operational Analysis Support to NATO Operations

SAS-088, Long Range Forecasting of the Security Environment

SAS-084, Planning, Decision Support, Systems Analysis and Knowledge Development: A Technology Roadmap

SAS-083, Power and Energy in NATO Operations

SAS-082, Disruptive Technology Assessment Game: Extension and Applications

SAS-075, Characteristics of Future Expeditionary Operations

SAS-074, Integration of Psycho-Social Models and Methods in NATO's EffectsBased Approach to Operations

SAS-066, Joint Operations 2030

SAS-062, The Impact of Potentially Disruptive Technologies

\section{United Nations}

\section{Millennium Project}

The Millennium Project, founded in 1996 after a three-year feasibility study with the United Nations University (UNU), Smithsonian Institution, Futures Group International, and the American Council for the UNU. By now it is an independent non-profit global participatory futures research think tank of futurists, scholars, business planners, and policy makers who work for international organizations, governments, corporations, NGOs, and universities. The Millennium Project manages a coherent and cumulative process that collects and assesses judgments from over 2,500 people since the beginning of the project selected by its 40 nodes around the world. The work is distilled in its annual "State of the Future," the "Futures Research Methodology" series, and special studies, including "Global Exploratory Scenarios - 2025" and "Global Energy Scenarios -2020."

Further information is available in the Annex 5 to this report. 


\subsection{RELEVANT METHODS FOR EXPLORATION OF EU ROLES AS A GLOBAL SECURITY ACTOR}

Compared to other FOCUS 'big themes,' historical evidence of CSDP/ESDP missions and other relevant operations is scarce. In addition, decision making, operations planning and the actual conduct of such operations is extremely context specific, on occasion depending on minute detail. And then for certain types of operations, that could be undertaken in the future, there is only anecdotal evidence, if any.

Hence, 'hard' quantitative models and methods do not find use in foresight of future roles in international security. The exploration of EU roles as a global security actor is thus intrinsically subjective, intuitive, with creative processing and interpretation of expert knowledge.

That specific of FOCUS working package 6 defines the selection of methods overviewed in this section of the report.

The Delphi method is based on structural surveys. It is one of the widely used methods in exploring future developments, especially when it comes to looking 20-30 years into the future. It is intrinsically subjective and intuitive. Delphi involves a group of experts responding anonymously to questionnaires and feedback to the group of participants by the moderator, offering an explanation why certain judgements have been made. Then the cycle is repeated until study objectives are met.

Morphological analysis is the most structured method applicable to the study of future EU roles as a global security actor. Developed in the 1960s as a method for structuring and investigating the totality of relationships in multidimensional, non-quantifiable problem complexes, it was initially applied for purposes such as classification of astrophysical objects and development of jet and rocket propulsion systems (Ritchey, 1998). Since the 1990s it is applied in policy analysis and futures studies, benefiting from advanced computer support. It relies on judgemental processes and strives to provide internal consistency, rather than trying to identify and explain all cause and effect relationships. The method assists the discovery of new relationships or configurations in the design of scenarios and sub-scenarios, which may be overlooked when less structured methods are applied. It also facilitates identification and investigation of boundary conditions in the problem space.

Another method used in foresight is known as back-casting. Its implementation starts with a definition of a 'future' and then tracking back to find out those factors (drivers), trends, policies or programmes, that would bring us to that 'future.' The method has been used primarily in environmental studies, but is considered applicable in validating assumptions and findings in security foresight.

The application of structured methods as Delphi and morphological analysis is often combined with less structured ones such as:

Strategic culture analysis;

SWOT; and

Case studies.

Analytical Hierarchy Process (AHP) is also relevant to WP6 research, in particular for comparative assessment of alternatives, e.g. according to their contribution in meeting the requirements of a certain role, and consequent prioritization. 
Delphi, morphological analysis, strategic culture analysis, SWOT, case studies and Analytical Hierarchy Process were analysed during WP2 and presented in Annex 6 to FOCUS deliverable 2.1.

All these methods can be seen as complementary to the so-called scenario method, when scenarios are designed and used to evaluate and compare alternatives (e.g. strategies) and identify those factors, events, processes or trends that would have significant impact on the future and our policy choices.

Methodologically, most relevant foresight studies focus on the research process described originally by Peter Schwartz (1991). It includes a number of steps:

1. Determine the focal issue;

2. Identify trends and drivers;

3. Develop plausible futures;

4. Finalise drivers;

5. Flesh-out futures;

6. Derive key challenges and implications.

Using this as baseline, applicable methods are used at various stages to meet the requirements of the specific study (cf. Allied Command Transformation, 2009; Ratchev, 2009). For example, the adaptation used in the Multiple Futures Project is called Multiple Futures Intellectual Framework and described in detail in Annex A to its final report (Allied Command Transformation, 2009). 


\section{TRENDS, DRIVERS AND POTENTIAL STRATEGIC SHOCKS}

\subsection{TRENDS IN THE 2035 TIME HORIZON}

The strategic community widely shares the understanding that the world's future in the next couple of decades will be determined by the interaction of two basic factors: a world order based on a new distribution of power and interdependency among global forces and between them and the world community. The growing interaction between de facto changing power structure and interdependency at the global scale is revolutionising the system of international relations. Both are simultaneously loaded with many positive opportunities and charged with serious risks. Depending on which one dominates, one may expect different trends in the above mentioned key dimensions of describing future global roles of the European Union.

In the time horizon of this analysis there is no reason to expect that any single driver or trend will dominate the global developments. Drivers and trends are identified within the context of the specific theme; they are not for universal usage and may have various forms and impact on different regions and even European countries. In principle the drivers and trends are expected to be mutually dependent but this is not a rule; in some cases, they will work at cross-purposes (National Intelligence Council, 2000).

This section of the report provides information on key trends structured in five domains, respectively 'global order,' 'ideological,' 'globalised economic developments,' 'technological' and the 'environmental' domain.

Within the global order domain:

- Continuity of the strategic contractions of the U.S. unilateral role while its global strategic (comprehensive military) reach remains uncontested as a result of the lack of long-range capacities within other competitors, combined with their insufficient political will and interests in global engagement and taking responsibility.

Shrinking economic developments and growing costs of international military engagements may force the United States into a difficult set of tradeoffs between domestic versus foreign policy priorities (National Intelligence Council, 2008). Nevertheless, the United States will inevitably be engaged in international or multilateral arrangements to deal with growing transnational problems as economic and financial volatility, migration, piracy, terrorism, cyber security, drug trafficking and weapons proliferation. However, US unilateral operations in solving intra-state or interstate conflicts, especially out of the Western hemisphere, will be of an extremely low probability.

- Inter-polar world in which key players, EU included, create their own geopolitical spaces and military alliances and co-operate with each other on particular issues of common interest as a result of dominant influence of the constructivist approach towards global (security) affairs.

In order to be accepted as positive for the regional stability and prosperity, the creation of geopolitical spaces of influence-and control-by growing regional leaders should be based on the so called positive expansion. This means that the countries from the periphery recognise the role of the leader as a contributor to their national aims and interests. This usually requires that the leader provides investments, transfer of 
technology and management know-how, access to high quality education and research, free market and, not the least, protection of the interest of the region on the global scene of political, economic, and security relations. When that is not the case, the process of building 'own' geopolitical domains by the new powers may bring instead regional instability and conflicts.

- Decline of the role of international law as a result of 'moral inadequacy' of global players and its replacement by a balance of interest.

The respect to international law is a specific characteristic of the EU as an international actor. The nature of the role the Union may decide to perform will depend very much on the way other players respect the international norms and regulations.

\section{Within the ideological domain:}

- Spread of religious and ethnic radicalism both between cultures and within societies as a result of social diversification, political dissatisfaction and lack of modern education.

One of the most realistic explanations of the current turmoil in the Arab countries is that the openness brought by the process of globalisation has displayed the crooked face of authoritarian and dictatorship regimes. Their complete inability to manage economic and social affairs in an open and competitive world leads to clashes and even civil wars for reforms. At the moment of change, when there is a lack of any serious political idea and attractive leaders, religious and ethnic radicalism are instruments to quickly and decisively distinct oneself from the previous regime, showing at the same time ability to govern (which as a rule actually does not exist). In countries that have to cope with serious social dissatisfaction (especially from the youth) and economic difficulties, radical religious or ethnic based aspirations are likely to gain traction. The threat of radicalism could have interim character if the process of transition is directed by democracy-oriented forces. Otherwise the potential for conflict will increase.

- Decline of the attractiveness of the post-national state as a result of fear for social status and unpredictable future.

The attractiveness of any successful social model is an ideological factor. The role of the EU at the global scene will depend basically on the attractiveness of the European integration model. This is the only one that connects the human rights and political values with stability, non-violence, and social and individual prosperity. Any serious ambition of having EU as a respected global security actor requires that Europe remains a largely prosperous place. The probability that the people around world change their attitude in the coming decades and begin to look at EU in different context as dominant military power or empire-type leader is relatively small.

- Growing political nationalism that erodes the internal cohesion of the EU and feeds geopolitical rhetoric and ambitions.

Nationalism is the belief that the fate of a single person is bound up with the nation only and he/she is indifferent to the fate of others (Friedman, 2011). The sources of nationalism in Europe are well studied and explained but, if it succeeds in occupying an important place within the European political domain, two dangerous developments may occur simultaneously: re-nationalisation of national defence and abandoning any ideas about collective actions on the global security scene. Moreover, nationalism is inseparable from geopolitics of control. Sooner or later it will cross the border between 
raising another great national aim and trying to achieve it at the expense of neighbours. Despite how low is the probability of spreading nationalism to a politically important level, it has to be a permanent element in future analysis of EU security roles.

\section{Globalised Economic Developments}

- A global shift in the relative wealth is underway; in terms of size and speed, this shift is without precedent in history.

The global shift of wealth is mainly a result of the transfer of production activities from the West to perspective markets countries. Some governments of developing countries were clever to open their markets for investments and soon will enter the club of developed nations (estimated not only by GDP, but in GDP per capita as a criterion). Others, like Russia, missed this opportunity and continue to rely on the income primarily from exporting raw materials.

In the time horizon of the FOCUS study, this tendency may eventually lead to further economic difficulties in the EU and the United States and, in case of successful balancing of economic and social developments in the rapidly growing powers, to preservation of levels of productivity and efficiency of their economies. Some studies indicate that in the next 30-40 years "the overall GDP of the BRIC countries will collectively match the original G-7's share of global GDP" (National Intelligence Council, 2008).

However, this is a linear forecast. Neither the quality nor the technological level of the new powers' GDP will be compatible to those of the Western countries. China and India depend very much on the import of raw materials; Russia has huge reserves of natural resources but the political economy and the governance are in a need of total reform; Brazil and South Africa, as well as Iran, Turkey and Indonesia have the capacity to turn into regional powers.

In comparison with BRICS, the quality and capacity of the European economic base and its integration with that of the United States, the intellectual capacity and mentality of the people, and the quality of governance are stunning. The global shift of relative wealth may happen indeed or fail in time, but it is not an obstacle to the EU global role in the security domain.

- Important features of social transformation processes within Europe and the United States-and within the societies of the emerging powers-under the impact of globalisation are still unknown.

It can be expected that as a result of the global shift of wealth the middle classes in emerging global economic players will grow significantly. But serious political reforms are required in order to turn more affluent people into a socially determined middle class. Despite the huge income from the high prices of energy sources, there has been no growth of the middle class in countries like Russia. It is still not clear how the communist regime in China may solve this problem, and even whether it would be willing to solve it. In most other cases, the middle class is still more a sign of being different from the poor, than a social status of having independent and secure life. As a rule, the main source for the middle class are the state and local administration, the security forces, and people engaged in government-provided services as education, health, postal services, communications and transportation. 
From this point of view the globalisation may have an unexpected effect on the social system of Europe (and the United States). It is already obvious, that giant corporations with global operations are accumulating ever more power. However, their success and the openness of the markets for global competition are putting the small and mid-sized businesses, which are the backbone of the 'instant' middle class, in a difficult perspective. Eventual labourisation of the middle class could be a very serious shift that will affect directly not only internal political process (in terms of feeding nationalism, protectionism, and populism), but the decision-making at EU level.

In terms of social developments the giant international corporations will establish their own social system in the regions of operations (often these are cross-border regions, especially in South Asia). The package of social benefits in parallel with those provided by the governments would be relatively more attractive. This is well known from the history of capitalism and may be expected with high probability.

The continuing demographic decline in Europe will continue to parallel large migration. Fitoussi \& Laurent (2009) visualise main trends using UN Population Division data (see Figure 1 and Figure 2).

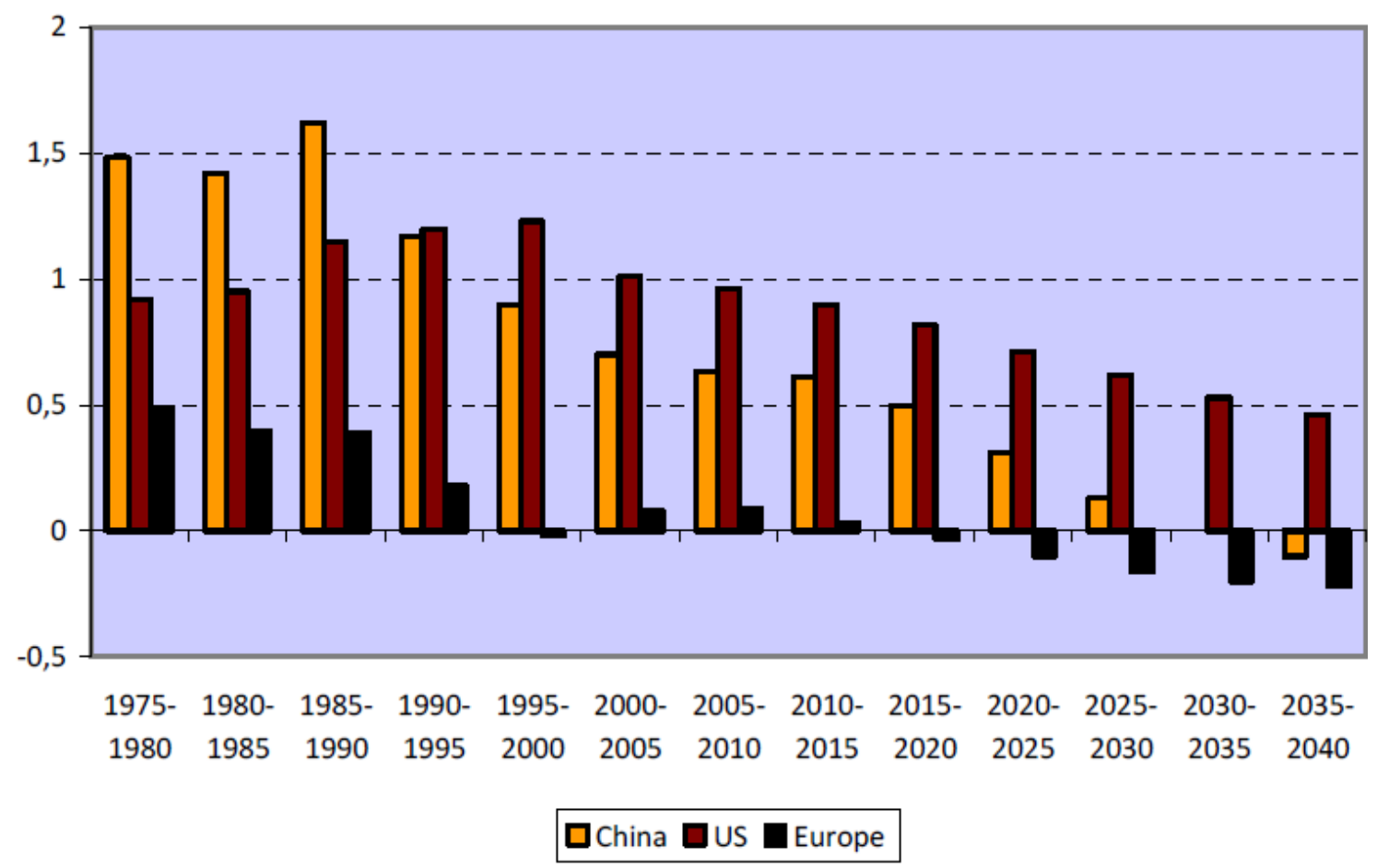

Figure 1: Population growth (in percentages), medium variant.

The problem with aging population is not only an economic and social problem. It has indirect and direct impact on the European decision-making process on external security actions. Older people, focussed on pensions, social and health service, are more conservative towards the global affairs and less susceptible to appeals to support engagement in risky and costly missions. 


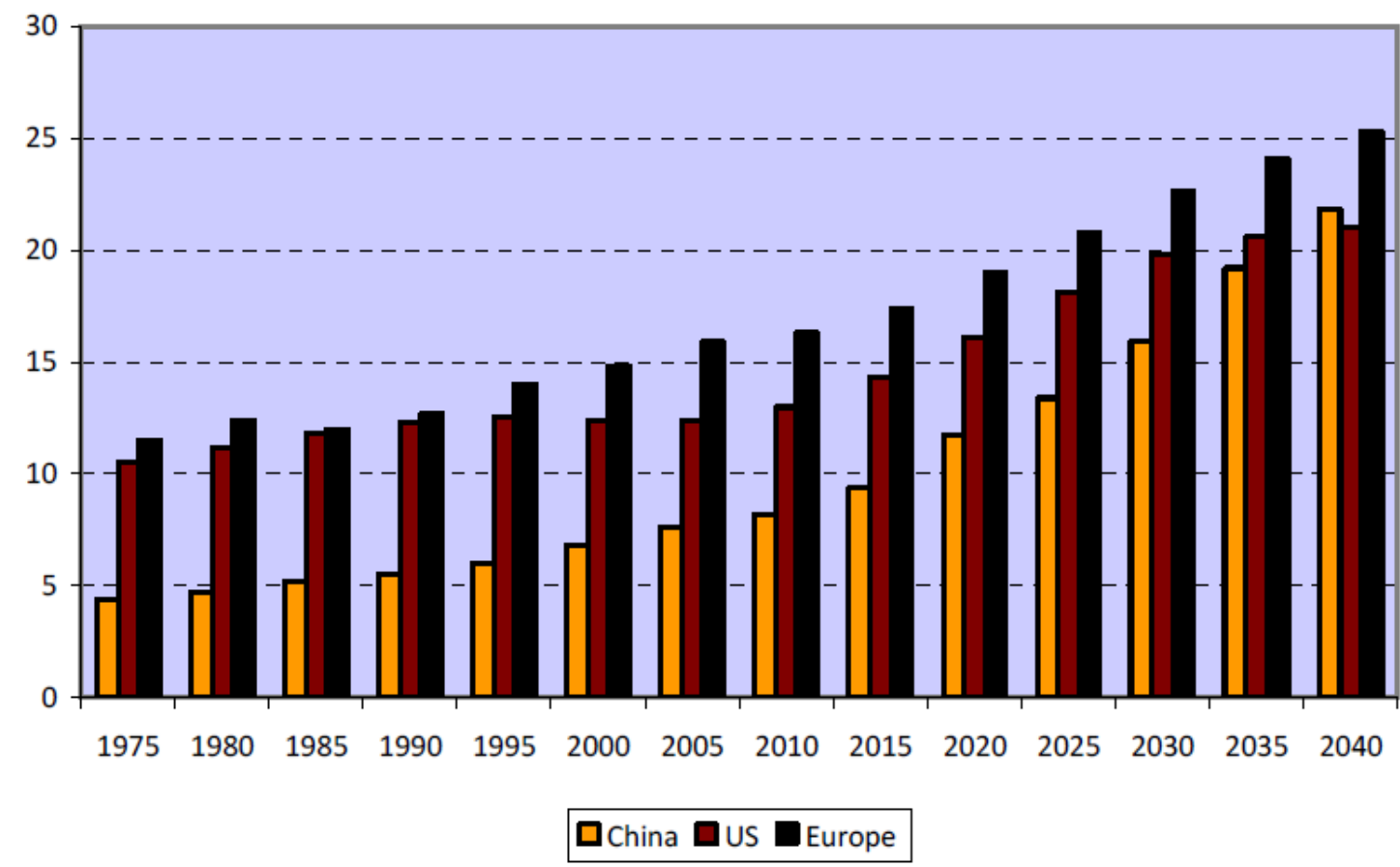

Figure 2: Population aged 65+, medium variant (in percentages of total population).

Europe will continue to attract migrants from Africa, the Middle East, South-East Asia and Eastern Europe. The most serious analytical challenge in the 2035 time horizon is expected to come from Africa, where the population is likely to double. The case of Libya exposed a specific development within the Arabian nation - authoritarian governments prefer to invite low-cost foreign workers than to hire national youth educated on public money. Instead of jobs, they provide social help. The biggest food delivery social system in the world today is in Iraq, where the largest employer is the government along with local administration.

- Developments within global energy markets, especially the contradictions between tendencies of centralisation of control over resources and decentralisation of markets.

Within the time frame of 2035 the energy will continue to be the essence of the economic strategy. In this time horizon the supply of energy resources (Figure 3) will inevitably continue to be in the focus of EU CFSP and CSDP. The industrialised world will be separated in countries in which the demands of classical energy sources will grow up and countries (mostly Western) that will be in the midst of energy transformation (National Intelligence Council, 2008). From the point of view of the EU global security role two types of problems emerge: first, the concentration of the production of oil in half a dozen of countries that will form a specific international security actor and the fact that in all of them the oil business is completely state-owned or delivered through oligarchic structures. This means that the security of energy supplies will be based more on political relations than on 'business as usual.' For the EU security roles, the energy aspect will be one of the most complicated and obviously will require increased efforts towards conceptualisation and operationalisation. 


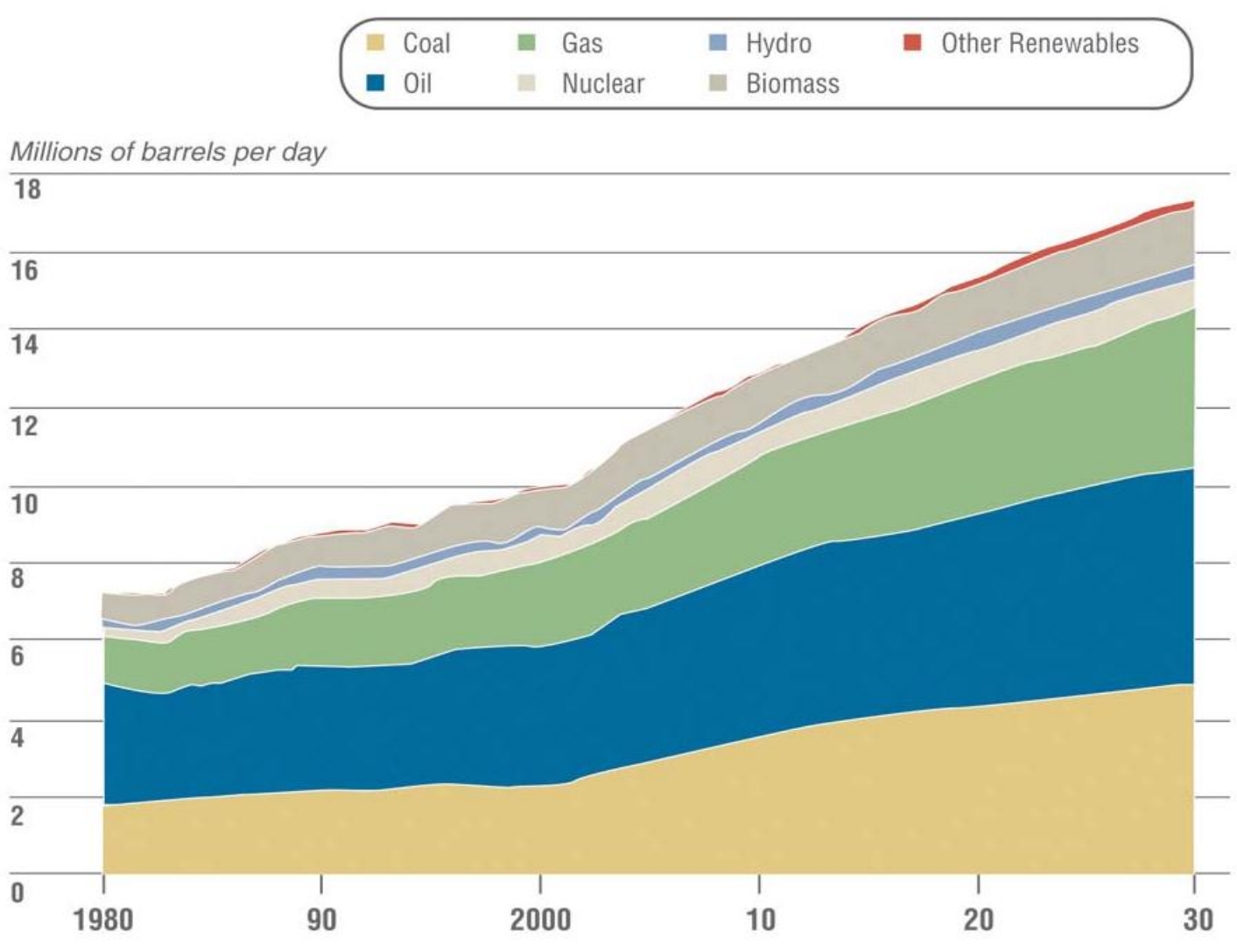

Figure 3: Breakdown of likely energy sources.

Source:National Intelligence Council (2008), based on data from PFC Energy International, www.pfcenergy.com.

\section{Technological Domain}

The following trends can be identified in the fourth, the technological domain:

- Technological competitiveness will bring new levels of global interaction and competition, especially in cyber, space, transportation, and extraction technologies, military and intelligence hardware and know-how, etc.

Technology was chosen as a principal trend because of its potentially transformative rolein both positive and negative ways -in addressing a wide range of international security challenges, related to the EU global role. While there is little doubt about the impact of technology on social developments as well as on the military and particularly on terrorism, the key questions in the 2035 timeframe are on the origins of technological innovations, who will be the innovators and who will use the products of their work.

In the context of the EU global security role two principal uncertainties need further research (RF\&GBN, 2010). The first one is related to the level of political and economic alignment in the world, but mostly within the circle of global competitors. This aspect is decisive because it will determine the quest for and the readiness for sharing high tech products and technology. The second is about the level of adaptiveness of global partners of the European Union. Adaptive capacity is not only about economy and use of technology 
but also about creating an environment of rules and procedures for technological exchange and co-operation.

- None of the other trends will be more important than the success or failure of efforts to prevent the spread of weapons for mass destruction and uncontrolled access to technologies and materials for their production and delivery.

Arms and nuclear control are in decline and this is opening up space for the uncontrolled spread of 20th century technologies to countries with regional leadership ambitions and to non-state actors. Aligning proliferation with geopolitics of energy (and water), regional dominance ambitions and/or strategic terror in neighbourhood regions constructs the only threat to EU's vital security interests. (Table 3 provides an overview of the status of nuclear forces by 2011.)

Table 3. Estimated status of nuclear forces in 2011.

Source: Federation of American Scientists. Retrieved from www.fas.org/programs/ssp/nukes/ nuclearweapons/nukestatus.html

\begin{tabular}{|l|c|c|c|c|c|}
\hline Country & $\begin{array}{c}\text { Strategic } \\
\text { Operational }\end{array}$ & $\begin{array}{c}\text { Nonstrategic } \\
\text { Operational }\end{array}$ & Reserve & $\begin{array}{c}\text { Military } \\
\text { Stockpile }\end{array}$ & $\begin{array}{c}\text { Total } \\
\text { Inventory }\end{array}$ \\
\hline Russia & 2,430 & 0 & 5,500 & 8,000 & 11,000 \\
\hline United States & 1,950 & 200 & 2,850 & 5,000 & 8,500 \\
\hline France & 290 & n.a. & $?$ & $\sim 300$ & $\sim 300$ \\
\hline China & 0 & $?$ & $\sim 180$ & 240 & 240 \\
\hline United Kingdom & 160 & n.a. & 65 & 225 & 225 \\
\hline Israel & 0 & n.a. & 80 & 80 & 80 \\
\hline Pakistan & 0 & n.a. & $90-110$ & $90-110$ & $90-110$ \\
\hline India & 0 & n.a. & $80-100$ & $80-100$ & $80-100$ \\
\hline North Korea & 0 & n.a. & $<10$ & $<10$ & $<10$ \\
\hline \multicolumn{1}{|c|}{ Total: } & $\sim \mathbf{4 , 8 3 0}$ & $\sim \mathbf{2 0 0}$ & $\sim \mathbf{8 , 6 5 0}$ & $\sim \mathbf{1 4 , 0 0 0}$ & $\sim \mathbf{2 0 , 5 0 0}$ \\
\hline
\end{tabular}

As the present situation indicates, the non-proliferation regime does not provide for optimism and further proliferation of nuclear weapons may be expected in the time horizon of 2035 (Strategic Trends Programme, 2007).

The core concern for EU will be the area between the Middle East and South Asia. The current status of South Asia, where the nuclear conundrum prevails, is a result of fluctuating international non-proliferation policy towards the region. With nuclear India and Pakistan, the prospect of nuclear weapons will embolden Iran, lead to greater instability, and trigger shifts in the balance of power in the Middle East. That appears to be the key concern of the Arab states in the region and may drive some to consider acquiring their own nuclear deterrent. According to the National Intelligence Council (2008) Turkey, the United Arab Emirates, Bahrain, Saudi Arabia and the former regimes in Egypt and Libya are or have expressed interest in building new nuclear power facilities. 
This is a complex challenge. Although there are several possible ways to address current aspirations of Iran and concerns about its nuclear programme, the response will almost certainly require revitalisation and reform of international control regimes on a global scale - an extremely complicated mission in itself (Brookings, 2009).

From this point of view, in the time horizon of 2035 effective deterrence with symmetric and asymmetric tools will be a compulsory element of the EU security capabilities and political power.

- Newly emerging characteristics of armed conflict

The Petersberg Tasks have been defined in a period of controversial policy on using armed forces for peace enforcement, peace keeping, sustainability and reconstruction operations held in different context, including the war on terror. The period between the first war against Saddam Hussein (1991), the NATO intervention against Serbia (1999), the invasions in Afghanistan (2001), Iraq (2003), and Georgia (2008), and the operation against Gaddafi (2011) presents almost the full spectrum of interventions at the level lower than 'global.'

However, these interventions do not characterise the full spectrum of armed conflicts. Intrastate conflicts based on ethnic-religious divisions and those for control over territory illustrate that at the local level armed conflicts are characterised by "... the kind of ferocity that was typical of 'modern' war, but overall casualty levels have been much lower" (Sheenan, 2010).

Most of the future armed conflict studies accept that in the perspective of the next two-three decades any war between global powers-existing and emerging-will be 'unlikely' (National Intelligence Council, 2000; Gurzon, 2008; Strategic Trends Programme, 2010), mainly because of the economic and financial interdependence, analysed above, loose military alliances and, obviously, insufficient comprehensive capabilities to transfer any high intensity military operation into sustainable political effect. Some analyses like the one in the Strategic Trends Programme (2010) stipulate that in general "the risks of inter-state war may increase beyond 2020 when intensifying competition for resources, particularly energy and possibly food, and continued population growth result in heightened tension."

However, the very nature of war probably will not change substantially in terms of 'achieving political aims with military means,' but the character of conflict and war will constantly change and evolve. Dedicated studies identify the following main drivers of change:

- Globalisation is changing the foundation of the modern era 'war and defence issue' - sovereignty of the national state. It is eroding not only the economic autonomy but also the political, informational, and cultural (language, knowledge, education, media) aspects of sovereignty (Sheenan, 2010). In such tendency neither the centre of gravity of a military operation, nor the strategy and the means could be decided adequately in the application of known methods of contingency planning.

- Increased number of states and non-state actors, equipped with various weapons of mass destruction, will create a more difficult environment for interventions and will affect the ability to undertake interventions. Operations that threaten personal or regime security of autocratic leaderships in nuclear-armed states will entail particular risks (Strategic Trends Programme, 2007). 
- Advances in information technology would enable new synergies in war fighting through the combination of advanced precision weaponry, improved surveillance, reconnaissance, targeting and enhanced command and control capabilities, and expanding use of artificial intelligence and robotics.

- Developments in cyber, nano, robotics, space, networking, and other technologies may create in a period of two-three decades another level of asymmetry and introduce what some authors refer to as 'fifth generation warfare' (Hammes, 2007).

- Hybrid-type conflicts will proliferate due to a mixture of state and non-state actors and terrorist networks, expanding the possibilities for combining cyber attack capabilities with urban warfare assets. This type of conflict is closer to the specific theme of the EU's Petersberg tasks. Margaret Bond (2007) has argued that they will require "... a new approach to using our armed forces for a broader and more comprehensive war of scale, ranging from purely peaceful humanitarian missions as preventive measures, to the development of hostile conditions, through traditional war fighting operations employing traditional combat strategies, to post conflict reconstruction and stabilization efforts, where security and peace derive from thriving economic and political status."

However, in the time horizon of 2035 an imaginary 'virtual' war where complicated robotics integrated by information systems using high precision weapons to achieve quick 'victory' with few casualties most probably will not realise. As a minimum, such a paradigm could not serve as the ground for planning capabilities for the Petersberg tasks. Van Creveld (1991) and Kaldor (1999) examine in detail this issue.

\section{Environmental Domain}

The following trends are identified within the fifth, the environmental domain in the 2035 timeframe that may impact decisions on EU security roles (cf. Homer-Dixon, 1994):

- Visible impact of the environmental degradation on vital natural resources such as water, energy and food as a result of continuing industrial policies without parallel investments in ecological preservation;

- Increase in the immediate danger of raising sea levels, especially in the northern hemisphere, as a result of failure of comprehensive international efforts towards environmental protection.

\subsection{DRIVERS OF CHANGE}

To understand the potential future global role of the EU in the security domain, it is necessary to understand the factors that may drive change from the contemporary point of view. The drivers of change approach is applicable to both mid-term planning based on trend analyses and extrapolation and long-term planning based on foresight scenarios. ${ }^{9}$

9 The concept of change as a driver (a major cause) of the new global security environment is based on the works of authors like Alvin Toffler (Future Shock, 1970; The Third Wave, 1980; Powershift, 1990) that have studied 'waves of change' from a historical perspective. The FOCUS research team accepts that in the 2035 time horizon the system of international relations will be facing not only incremental, but also radical developments and that will affect every aspect of the EU construct. The drivers of change are elaborated here from the point of view of the specific theme - EU global security roles. 
In this approach change, similar to the term challenge, includes a negative as well as a positive notion. Its dualism comes from the fact that one and the same development may be seen from one point of view as a positive and as a negative from an opposing or a different point of view. However, the basic characteristic of change is that it closely affects core interests, values, or principles of the specific subject under study - the EU global roles in the security domain. The discussion on drivers of change in this case means a discussion on having or not such a role, of having leading, supporting or marginal role, of having defensive or offensive behaviour while implementing the role, of performing the role autonomously, within a formal alliance or in ad hoc format, etc. The common dominator of all drivers of change identified within the specific theme is that as a whole and independently they require hard decisions which are often connected with difficult political choices, mobilisation and delivery of significant resources, and normative, institutional, and functional redesign.

While studying drivers of change with social and political character, available study results have identified a number of components. For example, NATO's Multiple Futures Project is based on structural and deterministic drivers. Some of them, that have been very influential throughout history, are designated as structural:

Friction is a result from the distribution of power in international security affairs and is measured by the degree of ease with which decisions are made at the international level, ranging from cooperation to confrontation;

Integration is derived from the economic aspect of globalisation;

Asymmetry reflects the relative difference between the capacity of states to influence international security affairs.

Deterministic drivers are those developments within the context of the structural drivers that will have the greatest impact on security in the coming decades: changing state capacity, resource allocation, climate change, use of technology, demographics, and competing ideologies and world views (Allied Command Transformation, 2009).

The UK Department for International Development uses three components in their analysis of drivers of change:

- 'Agents' refers to individuals and organisations pursuing particular interests, including the political elite, civil servants, political parties, the military, etc.;

- 'Structural features' includes the history of state formation, natural and human resources, economic and social structures, demographic change, regional influences and integration, globalisation, trade and investment, and urbanisation;

- 'Institutions' includes the rules governing the behaviour of agents, such as political and public administration processes.

While building scenarios for EU 2020, Bertrand, Michalski \& Pench (2001) used a relatively large number of drivers. This approach is also rational because it provides better grounds for building relevant and plausible scenarios. As components of structural type they use technology/work organisation, culture/values, governance politics (public and administration), EU institutions, labour market and social policies, other economic policies, globalisation, and regional security (Mediterranean, Central and Eastern Europe, USA, Russia, and Asia). 
The FORESEC Project in its Deliverable D4.5 identified the following drivers of change for European security: global power shift (the structure of the international system), growing complexity (the nature of security and security risks), energy security, demographics, terrorism in Europe, nuclear proliferation (threats to European security from a nuclear Iran), extreme environmental events, and critical infrastructure vulnerability (Giegerich \& Comolli, 2009).

One of the principal works exploring the American role in new strategic perspective (Institute for the Study of Diplomacy, 2008) uses the following set of drivers of change: science and technology (information, biology, genetics, and nanotechnology); global production networks; job outsourcing from developed to developing countries; American consumers; Chinese suppliers; Asian commodity importers; developing country youth bulges; aging populations in developed countries; global warming leading to soil erosion, species extinction, and climatic upheavals; scarcity of clean water for growing urban populations; health pandemics; Salafist terrorists and other technologically empowered individuals; non-governmental organisations; religious revivalism; nationalism.

The UK Development, Concepts and Doctrine Centre in its Global Security Trends - Out of 2040 is using the concept of 'ring road issues' to explain the structural "key drivers of change that will affect the lives of everyone on the planet over the next 30 years" (Strategic Trends Programme, 2010). As structural components the authors recognise globalisation, climate change, global inequality, and innovation. Within their context four key themes have been identified - the human environment, dynamics of global power, evolving defence and security challenges, and strategic shocks.

What those and many other works reflect is that a single blueprint approach to drivers of change analysis is inappropriate. A conceptual model for the EU global role in security has to be developed to incorporate and better understand the interaction between components affecting both positive and negative change. Each component of structural or deterministic character can affect the others and vice versa. However, the impact of one on the other is mediated through the role of the 'institution European Union' as an actor in the global security affairs.

As mentioned above, EU already has a global role, including in the area of external security. However, this role has been initiated and applied more or less within the Bretton Woods system with its three pillars: the concentration of both political and economic power in the hands of a relatively small number of Western states, the existence of a cluster of important economic and political interests shared by those states, and the presence of a dominant power 'willing and able' to assume a leadership role (Spero, 1985).

As the global hypothesis explains, this system of conditions that forms the fundament of Western dominance is under a gradual reconstruction in favour of the new economic, demographic, and plausible military powers. Therefore, the set of drivers of change should be identified in the context of those characteristics of the plausible future that have structural and deterministic impact on the EU future security role. The determination of roles and missions on behalf of the EU is not trivial, especially when EU roles on the global scene are under consideration. Difficulties stem from conceptual, legal, organizational, economic, political exigencies, capabilities, cultural, social and environmental considerations. In the exploration of these roles it is necessary to encompass different forms of EU action, i.e. as a unified player, as a normative actor, as a societal power, or other kind of actor.

Following this set of considerations, one may identify those trends and drivers that could be regarded as likely to have an important impact on the future EU global security role. Therefore, it is possible to distinguish between three types of drivers: structural, deterministic and institutional. 
Structural drivers of change for the EU global role are the ongoing diversification of power, the interdependence in economic, political, and security aspects, and the governance as a main factor of generating positive or negative decisions and action in the field of security.

Diversification of power is not a synonym of power sharing or distribution of power. Diversification is of a much more comprehensive character. The term refers to different kinds of sources of power, different forms of power, and different ways of using power on the global scene. Differentiation will come out from the tendency of distributing the traditionally state-owned power to the private national and international actors which in many cases are or could be from the opposing side. The future forms of application of power will have much more virtual, financial, and social character, than physical. The power will be used mainly indirectly, using different open and covered channels of influence. The main reason for such deep change is the character of the powers that will expectedly play crucial role at the global scene. Countries like China, India, and Brazil, but also Russia, Iran, and the Arab nation represent civilisations with specific values and traditions, quite different from those of the West. Some of them completely lack experience on the global security scene and have to learn what to do with their growing capacities. As a rule, they all believe that a split and confrontation between the US and Europe is in their strategic interest. As a result, the diversification of power in the coming decades will be a much more complicated process than the simple redistribution of power.

Interdependence in this case is an effect from economic globalisation and integration that leads towards political and security commitments that may be formal or informal. Future security commitments will come not so much from the values and ideas (as was the case with trans-Atlantic integration), but from geo-economic and geopolitical interests, access to strategic raw materials and resources and routes of transportation, radical reforms in the field of labour market, gaining access to research and technological capabilities, etc. In many cases the interdependence will be driven by non-state actors - giant international corporations, banks, transportation companies, and others will predetermine governmental political decisions. From this perspective, interdependence differs from integration because it is mostly of a compulsory nature. In order to be a source of stability, interdependence should be based on a positive expansion from those that have more to others that have less. Otherwise, it may turn into a source of resistance and search for compensatory solutions (e.g. military alliances).

Governance in terms of level of responsibility and commitment to the legal international norms would be a structural driver in the coming decades. The above mentioned developments and the unpredictable consequences of furthering economic globalisation will create a complex environment for any government. The pressure will come both from national societies and international environment. As a profound effect of globalisation, in some countries the middle class will grow rapidly, while in others, including in the developed world, it may considerably decline due to the outsourcing of production capacities. The next generation of crises in advanced societies will not be a financial or economic, but one of jobs. The pressure over the governments will come also from complex international relations in which they have to deal not only with those neighbours that they know well but with governments of far away countries. The spread of information and the communication abilities of the people will create specific atmosphere for the governing bodies where their effectiveness and efficiency would be checked via increased transparency and accountability. Part of the pressure on governance will come from new forms of identity politics centred on religious convictions. In a rapidly globalizing world experiencing population shifts, religious identities provide followers with a ready-made community that serves as a social safety net in times of need, which is particularly important to migrants (National Intelligence Council, 2004). Last but not least, there is a tendency of growing importance of the national legislative powers; this is a fact even now for countries like USA and Iraq, but also for the EU. 
Deterministic drivers of change that will have decisive impact of the EU global role in security in coming decades include:

Further effects of globalisation that may lead towards a global shift in relative wealth, revival of geopolitics, enhancement of global disorder and a new form of multipolarity;

Evolving exogenous threats and challenges to the vital aspects of EU security such as sovereignty of Member States, the functioning of its common market, unhindered access to strategic resources, strategic terror, security of common cyber networks, security of other critical infrastructure, energy security, etc.;

Any long-term significant change in the 'average weather' that may have an impact on international relations;

Relative economic power of the EU vis a vis other global centres of power;

European perception on own economic and financial conditions that will affect the ability and willingness of the Member States to increase their collective efforts on the global scene;

EU internal political and social cohesion that will determine the sense of collectiveness and readiness of taking responsibility and sharing the burdens of a global role including an increase in regional co-operation and integration vs. global multilateralism;

European demographics that may strongly influence public attitude and political will to act at the global scene as an independent actor;

EU-US relations as an essence of the 'West' and 'Western civilization' and particularly the common threat perception, burden sharing through NATO and the relations between the latter and the EU's CFSP and CSDP;

EU relations with other strategic partners in terms of avoiding violent competition and readiness to cooperate and share the burden of maintaining global peace and stability, respect for human rights, enhancement and implementation of arms control and non-proliferation regimes;

Dedication to the protection of human rights, globally, as a principal value of the EU;

Mass migration and cultural co-existence on European soil in relation to other factors such as European demography, economic stability, capacity to integrate, and public attitudes towards 'the others';

Consolidation of EU CFSP and CSDP as a set of principles and decision-making mechanisms, i.e. the interplay among European institutions and Member States.

Institutional drivers are important because if they are used properly they may soften the frictions produced by the structural and deterministic drivers. Institutions include the rules governing the behaviour of security actors, such as political and public administration processes, EU decision-making on foreign, security and defence issues and the international intergovernmental organizations. They include formal as well as informal rules. Specific actors are the non-governmental organisations and media with capacity to influence both national and EU level decisions. Institutions can affect structural features and vice versa. Institutions are more susceptible to change in the medium term than structural features. This leads to the conclusion that institutional performance is important to understanding change processes and the impact they will have on the EU global security role. However, in the coming decades the institutions-both international and domestic-are very likely to be an object of pressure for reforms. As Kerremans 
(1996) put it, "the new-institutionalism will not only point at the rules and traditions but also on routinisation and socialisation." For this reason further security research should address not only formal rules, but also informal rules, power structures, vested interests and incentives within these institutions.

\subsection{POTENTIAL STRATEGIC SHOCKS}

The alternative futures of international security are not driven by distinguishable trends and recognisable drivers only. Events like the oil crisis of the 1980s, the collapse of the Soviet Union in 1992, terrorist attacks such as on 9/11 2001 or the financial crisis of 2008 have the capacity to deteriorate the impact of certain trends and to generate new drivers. They have multi dimensional effects on different aspects of the international relations and the behaviour of global actors. One of the specific effects may be the emergence of a new actor, like the case with OPEC in the 1980s, or even a new type of actor, as was the case with Al-Qaeda. As a result from such specific developments or events (strategic shocks) the context of the security environment may change in some of its principal dimensions.

The medium- to long-term effects of strategic shocks are difficult to forecast mainly because of their unique character, high speed of occurrence, and the necessity of a-typical management responses. Strategic shocks in the security domain are characterised also with focussed effects on international security relations, including on defence alliances. The 9/11 attacks on the US soil and the consequent US war on terror put NATO and trans-Atlantic relations under a vigorous trial.

Having in mind that the globalisation will inevitably lead to establishment of more interrelated systems, the effects of different shocks may generate systematic crises of global security. Impacts are differently assessed from the distance of time; it may be therefore beneficial to evaluate them initially as potential challenges, at least for the EU. The breakdown of the Berlin wall was a shock with a positive character for EU and USA, but at the same time seen as a negative challenge or even a source of threat by Moscow.

The selection of issues that may turn into strategic shocks in the future is based not so much on historic associations but on facts that exist in contemporary reality in some form. The following developments may occur in the time horizon of 2035 as strategic shocks:

- The death of the common currency after a cycle of crises that may lead to degradation of the EU down to a common economic space.

Such development will have cascading effects for the EU, both internally and externally. It will lead to a transformed economic, social, and security impact for the Member States and the common construct that will probably totally undermine the ability of the EU to act at the global security scene.

- Prolonged difficulties of a major state, which could directly affect the European security in a comprehensive manner. Several types of pivotal states are important for the functioning of EU as well as for its global security impact:

Russia is both a strategic supplier of raw materials and the only nearby military power, proportional to EU capacity. EU is the major economic and political partner of Russia and its main source of hard currency. In the estimated time horizon Russia will continue to be a major energy supplier, especially if it changes its investment policy and attracts 
European and US resources and technologies for drilling and up-streaming of oil and gas in the far North. This interdependence will continue to drive the relations between the two entities. At the same time Russia will continue to experience difficulties in restructuring its economy, dealing with artificially established private monopolies, establishing the rule of law, and in the overall democratic performance. Special concern for EU is not the ambition of Russia to build its own integration project but its aims and the way Moscow tries to achieve them. From this point of view Russia is part of the principal EU new security dilemma. A strategic shock from Russia is of relatively low probability.

Collapse of any of the major energy suppliers such as Saudi Arabia, Iraq or the smaller Gulf countries, Nigeria, Angola or Iran will have mainly a regional impact but will trigger domino effects for the EU. These countries have significant currency reserves as a financial buffer, but their mono-political economy, based on the income from hydrocarbons only, could not be restructured in a short period of time. Having in mind that most of the oil reserves in these countries, Russia included, are depleted to less than a half (with the exception of Iraq and UAE), reforms during the next 20-30 years will be of dramatic importance not only for them but for EU as well. Protracted difficulties in each of those countries or failure of reforms could be caused by different sources with political, ethno-religious or regional security character. While they are extremely centralised and the dependence of people on the state is dominant such reforms may produce tremendous social turmoil. As a result, the probability of a strategic shock from those countries is of a 'medium+' probability.

China is a major trade partner of EU and a source of financial resources for stabilisation during the current crisis. The interest of China's leadership and business of obtaining European production capacities and infrastructure may lead to a different situation in a mid-term perspective. At the same time, the country will continue to exploit the complicated political and economic situation, contradictory internal politics and a regional security policy raising serious questions. Having in mind the interconnectedness of these major elements of Chinese realities, any protracted difficulties are of a 'medium+' probability.

Turkey is the 'next door China' for Europe. The similarity with the Asian giant is in the dynamic economic development (Turkey's GDP is close to the Russian one, but with a completely different structure) and specific political system. The internal political vulnerability in Turkey does not come precisely from the military but from the pendulum between islamisation and secularism. There is no solid evidence how powerful are these two trends. Islamism is grounded not so much into the religion itself but into the achievements the Ottoman Empire had under the flag with the crescent. Secularism is in everything else, including into the specific role of the military. The external sensitiveness of Turkey comes from the intensity of its ambitions to build its own space of influence that may lead towards a future integration project. This ambition is not new. It has started with the revival of Turkey's economy in the second half of the 1980's and was explained by the then premier Turgut Özal as Turkey being the fatherland between the Adriatic Sea and the Great Chinese wall. However, today's Turkish strategy (explained by the foreign minister Davutoglu when he was just a professor as 'strategic depth') is much more coherent and focused on concrete regions as the Balkans, Black Sea, Caucasus, Central Asia, Middle East, and North Africa and on important global security issues like the Iranian nuclear programme and the Middle East Peace Process. Turkey's officially declared approach of having 'zero problems' with neighbours is 
constructive and may be estimated as productive in some cases like the Western Balkans, Iraq and North Africa, but in other cases like Israel and Palestine it has produced serious international contradictions. Turkey is also the only country with which an EU member state has a conflict with a possible military dimension. As a result, any serious and protracted difficulties in Turkey or eventual collapse of its internal stability may cause complex problem for EU in its immediate neighbourhood, waves of migration, including from other countries to which Turkey has provided a visa free regime, and internal difficulties with about 10 million Turks living permanently in the EU. The need of an EU member state to receive military support for defence should not be excluded. A strategic shock from Turkey is of medium probability.

The expected shift of the focus of the United States towards the Pacific should not be estimated as a potential strategic shock. The mutual interdependence between the two entities-the EU and the United States-is immense and vibrant and will survive during an eventual transition. Ties in political, military, economic and research and development areas are vital for the functioning of both entities and either of them would have no substitutes because this is and will probably continue to be the only complex alliance with global impact based on values and ideas.

- Identity based conflicts or territorial disputes on European soil or in the close neighbourhood.

Potential conflicts grounded in identity, ethnicity, and religious divisions are not yet fully eliminated from the European perspective. They exists in the hart of Europe - the Western Balkans, in the close European neighbourhood - between Greece, Turkey and Cyprus, and in an environment at a medium distance - in North Africa and the Middle East, the Caucasus, and in Central Asia.

Dangers may well persist as the impact of globalisation extends further, deeply dividing countries in beneficiaries and losers. In the former case, aggressive nationalism will probably rise as a driving force aimed to find a solution of own difficulties with regard to 'the others.' In the latter case, questionable geopolitical ambitions may arise and drive regional policies near European soil.

Other events that may act as strategic stressors and shocks on international security relations may be found within the following:

- Discovery of an efficient synthetic fuel or an advanced technology of up-streaming of shale-gas and oil from sands that may have major global impact on international relations and thus help to reduce the destabilising impact associated with the expected 'resource wars' in the years ahead.

Such a discovery, if it is made globally available, will change completely the status of countries like Iran, Saudi Arabia, Iraq, Nigeria, and especially Russia as resourcebased actors in international economic and security relations.

- Nuclearisation of one or more countries in the Middle East that will require specific preventive, protective and defensive measures.

This opportunity is obviously realistic and should not be described as a shock, but the effect for the EU and international community may come from the speed with which such development may turn into a threat. 
- Terrorist strategic attack against an EU Member States and major allies or terrorist attack against any country with weapons of mass destruction.

- Malicious attacks utilising electromagnetic pulse technologies or coordinated cyber attacks and leading to the collapse of the European and US global communications and navigation grids, and limiting as a consequence the global access of the West.

The experimental strike-down of a satellite by China in January 2007 opened the curtain of an on-going arms race in space. In February 2008 the US launched its strike in order to demonstrate advanced capabilities. Such developments confirm that the work on space war capabilities is ongoing and show how vitally important for the global powers is the control over space.

- Emergence of unexpected serious and rapidly growing impact of climate change, e.g. higher sea levels, or another natural catastrophe that may have a dramatic impact on European citizens and Member States' territory.

Potential specific challenges and especially unexpected strategic shocks are issues that may be identified and elaborated exclusively by systematic foresight work based on random monitoring of variety of factors from social and ethno-religious, through climate and resources, to research and technologic development. 


\section{FRAMEWORK FOR EXPLORING EU GLOBAL SECURITY ROLES}

Recently the EU emerged as one of the most unusual and wide-ranging political actors in the international system (Ginsberg \& Smith, 2007). Historically, such a role has not been expected neither by the fathers of the union nor among observers like H. Kissinger, E. Haas, S. Hoffman, D. Allen, and others. As a compromise, some of them later have recognised the global economic role of the EU but mostly continue to believe that EU will not engage in security affairs where the US will have the role of the global policeman, as R. Kagan has argued. However, a popular recent report argues that the institutional place of the EU in the international system "now becomes an urgent and inescapable part of the strategic challenge that Europe faces in the world" (Emerson, et al., 2011).

The Union's global security role is based on 1) self-declaration of the level of ambition, 2) actions, undertaken at the international and global scene for solving important and 'hot' international issues, and, as a result, 3) the fact of recognition of the EU achievements by other international actors - mostly the other global allies and opponents. As Rami G. Khouri wrote recently in regard to the United States' position vis a vis the Palestinian bid for U.N. recognition, "... power is something you generate by your actions, and credibility as an international political actor comes from harnessing your power and using it efficiently and wisely" (Khouri, 2011). Consequently, EU's influence in the security domain has to be explored as an integral component of its global political role together with the economic and cultural components. They all are reinforcing and supplementing each other and are indivisible neither from analytical nor from a practical point of view. The EU is already acting as a global actor, turning into:

- A real and essential factor in global political relations based on institutionalised relations with practically all intergovernmental organisations with global coverage, all major regional organisations and strategic partnerships with the US and each of the emerging powers;

- One of the main actors in solving global hot political and security issues like the Middle East Peace Process, provision of security and stability in the Western Balkans, reconstruction and development of Afghanistan, regime change in Libya, and the antiauthoritarian movement within the Arab people;

- Leader or major contributor to variety of international peace-keeping and stability and reconstruction operations in Africa, the Western Balkans, Afghanistan, and Iraq;

- Owner of the most attractive political and social project in history - the only one based on commonality of values and norms, not on interests only;

- The major exporter of novel practices in political performance, effective and efficient democratic governance with high degree of transparency and accountability, institution building, and regional co-operation;

- Decisive economic power in production and delivery of high-tech goods that determine developments in practically all sectors of global business;

- One of the major contributors to scientific and technical research and development, and engine of the global technological progress;

- The second largest military capability in the world with a capacity to engage on a global scale in up to mid-intensity operations. 
These recent achievements in each of the above mentioned components of the EU global role do not undermine the need to apply inter-disciplinary analytical methods in addition to the traditionally used realism and liberalism, institutionalism and functionalism, etc. In a study of the impact of the Lisbon Treaty on the institutional balances within the foreign policy field, Wessels and Bopp (2008) offer two alternative possible readings of the CFSP provisions: as a major step forward in developing the Union as more coherent and effective international actor with more supranational elements or as another demonstration of an ever-refined mode of 'rationalised intergovernmentalism.' In this context, in an earlier version of their work on literature reviews Ginsberg and Smith (2005) identified six major debates:

- Why does the EU need a foreign/security policy at all and why has this capacity grown over the past three decades?

- What impact on the outside world, if any, does the EU have?

- What is the relationship between EU foreign policy and EU economic integration - two domains that used to be separate?

- What are the unique institutional mechanisms of EU foreign/policy and how do they function?

- What is the relationship between EU foreign policy and domestic politics?

- What does the overall EU foreign policy system look like in terms of inputs, outputs, and feedback mechanisms?

The authors have concluded that the wide variety of research questions surrounding European foreign policy signals the need for a transversal approach to the issue "... to include processes such as (for example) delegation/agency, path dependency, task expansion, Europeanization, sources of international systemic change, and of course the perennial pursuit of national interests within and outside the EU context." In this context several principal issues should be considered by the research agenda:

\subsection{THE EXTERNAL-INTERNAL NEXUS IN THE EUROPEAN FOREIGN AND SECURITY POLICY}

The recent achievements at the international arena are products of the union's unique complexity of internal and external dimension. What is foreign for the EU is deeply rooted in, effected by, and have direct impact on internal relations between the Member States. At the same way, internal conditions, intergovernmental relations and institutional decision-making affect the foreign and security policy positions and actions. The analyses of the internal dimension of EU foreign and security policy are often dominated by the view that it is most of all about the decisionmaking process on external issues or action and about the character of the decisions as intergovernmental or institutional. Such a research approach would be correct if it does not ignore the fact that borders between internal and external security have been virtualised during the last two decades. Member States, while working on international security issues, have established a common threat perception that has an effect on mutual confidence and is the ground for collective security actions and measures. It is also a way to establish a frame of reference on key issues especially on probably the most important - the EU policy on enlargement. The latter integrates the external and internal considerations in the EU CFSP to highest extent. As this specific 
characteristic is visible from the day-to-day CFSP process, analytical studies often focus on artificial separation between external and internal conditions ignoring their transversal character.

\section{A frame of reference for assessing CFSP}

Wessels and Bopp (2008) underline that “... many scientific and political contributions have been made to assess the 'actorness' of the Union and, more specifically, its role in the international system" and point to the studies of Smith (2006), Bretherton \& Vogler (2006), Wessels (2005), Wessels \& Regelsberger (2005), Tonra \& Christiansen (2004), Knodt \& Princen (2003), White (2001) and Rhodes (1998). According to most of these studies, there are two principal issues to be discussed while defining the frame of reference: how to define the EU itself as a global actor, and whether to compare the EU to other powerful actors in world politics.

Concerning the formula of the EU global role, the authors have underlined the emergence within the analytical works of two basic concepts: 'actorness' and 'presence.' Whereas the former sees the EU on its way towards a full fledged, state-like international 'actorness' (cf. Sjöstedt, 1977), the latter qualifies the Union as a growing and increasingly important 'presence' in the international system (Allen \& Smith, 1998). A third interpretation sees the Union itself as a 'process,' which structures the EU internally and its external environment (Smith, 2006).

The principal options around which the research agenda of the EU global role in the security domain could be organised include:

- EU evolving as 'a state-like actor' with a 'superpower' status (Blair, 2000; Galtung, 1973). In this option CFSP and CSDP ought to be based on a shared threat perception and common interests. This would suggest a level of integration higher than the Union may achieve based on the Lisbon Treaty, or at least to see states surrendering national sovereignty regarding CFSP and CSDP. In such a case the EU global security role has to be based on common vital security interests, the achievement of which would require a dominant coincidence of threat perceptions and shared risk assessment. In reality, such consolidation could be generated in cases of emerging direct military threat to several Member States.

- If the EU is analysed as 'a normative actor' (Scheipers \& Sicurelli, 2007; Manners, 2006), then the CFSP and CSDP should be based on values, i.e. the code of conduct on the international scene. The research question is whether normative principles such as democracy, human rights, market economy, rule of law, and functional multilateral world order are globally applicable. To turn itself into a global actor, the EU must help shape the world order (regarding norms and 'normality' in global interactions). And to participate in that process, the EU must have the capacity, including military power, to be decisively active. This means sharing risks and the burden of resolving important global issues (affairs) and to be recognized by other actors (which would mean respect, willingness to interact and unavoidability of interaction).

Arguments against these options can be drawn from several analytical perspectives. Morgenthau's realpolitik accepts that in the international security relations there's no clash of interests and/or values, but merely one set of principles originating from one political reality, as pitched against another, coming from another political reality. Liberal constructivism accepts that interests are (or have to be) based on values. Marxism accepts that the values are a function of material reality.

Ginsberg and Smith have shared that "... it is unproductive to define EU solely as a functional regime, an international organization, an alliance, a collective security 
arrangement, or as a 'supranational state'." They believe that EU is "... a highly institutionalized multilateral forum for encouraging regular international cooperation on foreign policy issues among independent states"10 (Ginsberg and Smith, 2007:269).

The principle challenge here is that the European norms are already interpreted differently by other centres of power: 'democracy,' 'market economy' and 'human rights' have a different value or interpretation across Russia, China, the Arab world or Africa, for example.

Furthermore, there is a contradiction between values and strategy (as the relations with Libya prior to 2011 witnessed): values linked to democracy, political rights, peace, etc., are subdued in the pursuit of strategic objectives such as energy security and migration control.

- The third option is based on the presumption that the limiting factor for the above mentioned options is the sovereignty of the Member States. It brings the discussion back to the state-centric discourse and the parameters of the national security. To avoid this, authors from the Copenhagen school suggest examining the EU as a 'regional international society' (Buzan, 2008; Knudsen, 1999). If the EU is viewed as an 'international society' then the key conceptual questions are what kinds of threats can be directed towards it and what threats it would be able to cope with? These questions are reasonable as different normative bases of 'regional international societies' lead to a different dynamics and internal cohesion and, hence, their capacity to cope with threats (Whitman, 1998; Bull, 1982; Duchêne, 1972).

- Another option for the EU, conceptualised by the Copenhagen school, is to use securitisation and to designate problems in different areas as security problems, thus setting them on a 'normal' basis. And in reverse, through de-securitisation to treat security problems as problems of other policies.

- The EU can be examined also as a geopolitical system or 'empire' in the sense of the Watsonian Imperia of the English school (cf. Watson, 1992). Geopolitically, the EU is created on the basis of a nucleus that expands towards the periphery (positive expansion). Geopolitics here is about control, i.e. for security and peace, not for sovereignty.

This is a control over the internal space of the European Union, its periphery and the neighbourhood, and, in a global context, over the sources of risks and threats. The Empire is focused more on security and stability, not on the sovereignty of constituent nations.

- Several options, elaborated in other analytical works and policy papers, may be considered within the general frame of reference. Ginsberg \& Smith (2005) select the following among them: 'Soft power' (Nye, 2004); 'Peace power' (Ehrhart, 2005); 'l'Europe puissance' /‘European power'/ (Lefebvre, 2004; Solana, 2001); 'Model power' (Miliband, 2007); and 'Smart power' (Ferrero-Waldner, 2008).

10 Emphasis in the original. 


\subsection{THE CONCEPT OF THE GLOBAL EU POWER}

EU power has never been seen narrowly or primarily related to its military dimension, and most likely this will be the case in the time horizon of 2035 as well. Military capabilities are important and in some cases even decisive, but the EU has never had and probably will not have purely military aims in any international engagement. The list of aims and objectives of the Union at the international security scene in the Lisbon Treaty and other related documents is quite extensive and covers all areas of both international and national foreign and security policy.

In this context, the Union presents itself as an actor that is both ambitious and ambiguous. It is historically confirmed-and may be confidently projected in the future-that military interventions are destructive, just as complex, costly and risky will be the transformation of military success into sustainable political results. Nevertheless, building a concept of power based on elaborated alternatives such as 'soft,' 'civilian,' 'ethical' or 'normative' power, while ignoring or neglecting the military component or each of the mentioned concepts, is not suitable.

The concept of the global European power should address in a suitable way the basic EU characteristics in order to provide the most relevant package of power components to every particular case of engagement. The extreme negative example could be when foreign and security policy and actions are undertaken in a way that, while maximizing one type of effect, e.g. the military, could damage the most positive one - the social attractiveness of EU. The application of the comprehensive approach should not be understood as a practice only, but also as a conceptual ground for the EU global power.

In this context, of particular importance is the impact of the concept of power on the EU decision-making process. Keeping in mind the aim to make EU effective as a governing mechanism, it is important to put under analytical scrutiny decision options, e.g. to emphasise a single but risky approach or to act in a comprehensive, but costly and prolonged way.

\section{Measuring the impact of the EU's external security actions and foreign policy}

It is obvious from the above discussion that as narrow are the resources dedicated to the EU global role, as limited would be its impact assessment. The most popular approach - to evaluate the EU abilities to cope with concrete security threats greatly underestimates the EU's external power. Adopting a wider range of measures allows one to appreciate both direct and indirect types of impact, the general roles played by the EU at the global level (Allen \& Smith, 1996; Elgström \& Smith, 2006), and the EU's impact on specific issues (Ginsberg, 2001).

In most of the 'soft' aspects of foreign policy like development aid, international economic and trade relations, environmental protection, fight against poverty and illegal migration the impact of the EU role is uncontested. The ability of Brussels to influence the foreign policy of the Member States is also well studied and recognised.

Regarding the measurement of the results and effects of the EU performance at the global scene of comprehensive security it is 'natural' to compare EU to other global powers through their impact - expected, virtual or real, on the global security affairs. As at moment this have been done mainly in parallel to US global actions, political and analytical suggestions create the impression of 'or - or' evaluation. As a result, in many cases during the US 'war on terror' the comparison between the two powers were explained as a zero sum - the achievements of one have been presented or explained as failure of the other.

However, when examining foreign security engagements, one has to account for a number of considerations. The dramatic expansion of the EU's direct involvement in security affairs in 
recent years is a case in point. Ginsberg and Bopp (2007) argue that when EU acts in international security its engagements have multiple impacts: on the states who request EU security assistance, on the EU itself in terms of confidence-building, on other international security organizations (e.g. NATO, UN) when EU cooperates with them or replaces their forces with EU forces and personnel, and on non-EU members who participate in EU security actions on the basis of complimentary interests and values.

All of these effects can been seen where the EU endeavours to act across the range of the Petersberg Tasks. 


\section{REFERENCES}

Allen, D., \& Smith, M. (1998). The European Union's Security Presence: Barrier, Facilitator or Manager? in Rhodes, C. (ed.), The European Union in the World Community. London: C. Lynne Rienner, pp. 45-63.

Allied Command Transformation. (2009). Multiple Futures Project: Navigating towards 2030, Final Report. Retrieved from www.act.nato.int/multiplefutures.

Bergmans, H., Van der Horst, J., Janssen , L., Pruyt, E., Veldheer, V., Wijnmalen, D., Bökkerink, M., Van Erve, P., \& Van de Leur, J. (2009). Working with Scenarios, Risk Assessment and Capabilities in the National Safety and Security Strategy of the Netherlands. The Hague: Landelijk Operationeel Coördinatiecentrum.

Bertrand, G., Michalski, A., \& Pench, L.R. (2001). European Futures: Five Possible Scenarios for 2010. Manchester: Edward Elgar.

Biscop, S. (2004). The European Security Strategy Implementing a Distinctive Approach to Security. Sécurité \& Stratégie 82. Brussels: Royal Defence College (IRSD-KHID).

Blair, T. (2000). Speech to the Polish Stock Exchange on 6 October 2000. Retrieved from www.number10.gov.uk/output/Page3384.asp.

Bond, M. (2007). Hybrid War: a New Paradigm for Stability Operations in Failing States. Carlisle, PA: US Army War College.

Brookings (2009). Global Trends and Security in the Muslim World: Dilemmas for U.S. and Regional Policy, Doha Discussion papers. Washington, DC: Caban Centre at Brookings.

Buzan, B., Wæver, O., \& De Wilde, J. (1998). Security: A New Framework for Analysis. Boulder, CO: Lynne Rienner.

Council of the EU. (2004). Civilian Headline Goal 2008, as agreed by the Political and Security Committee on 7 December 2004, in view of its presentation to the European Council on 17 December 2004 as part of the Presidency report on ESDP. Available at http://register.consilium.eu.int/pdf/en/04/st15/st15863.en04.pdf

Curzon, G.N. (2008), Global Trends, Part 3: The Changing Face of Conflict. Retrieved from http://cominganarchy.com/2008/11/26/globaltrends-part-3-the-changing-face-of-conflict. ${ }^{11}$

Department for International Development. (2004). Drivers of Change. London. Retrieved from www.grcexchange.org/g_themes/politicalsystems_drivers.html.

Department of Homeland Security. (2005). National Preparedness Guidance. Homeland Security Presidential Directive 8: National Preparedness. Washington, D.C.: Department of Homeland Security.

Duchêne, F. (1972). Europe's Role in World Peace. In Richard Mayne (Ed.), Europe Tomorrow: Sixteen Europeans Look Ahead. London: Fontana, pp. 32-47.

Ehrhart, H.-G. (2005). Die EU und das Leitbild 'Friedensmacht': Außen- und sicherheitspolitische Konzepte nach dem Irak-Krieg. In Thomas Jäger, Alexander Höse and Kai Oppermann

11 This is an alias of a U.S. blogger. 
(Eds.), Transatlantische Beziehungen: Sicherheit, Wirtschaft, Öffentlichkeit, Wiesbaden: VS Verlad für Sozialwissenschaften, pp. 87-99.

Ellis, V. (2001). Europe Beyond The Millennium - Making Sense of Tomorrow. Brussels: European Commission - Forward Studies Unit.

Emerson, M., Balfour, R., Corthaut, T., Wouters, J., Kaczyński, P.M., \& Renard, T. (2011). Upgrading the EU's Role as Global Actor. Institutions, Law and the Restructuring of European Diplomacy. Brussels: Centre for European Policy Studies.

European Commission. (2011). First Annual Report on the Implementation of the EU Internal Security Strategy. Communication from the Commission to the European Parliament and the Council, $\operatorname{COM}(2011) 790$ final, Brussels, 25 November 2011. Retrieved from http://eur-lex.europa.eu/LexUriServ/LexUriServ.do?uri=COM:2011:0790:FIN:EN:PDF.

European Council. (2003). A Secure Europe in a Better World - The European Security Strategy. Brussels, 12 December 2003. Retrieved from www.consilium.europa.eu/uedocs/cms_data/ docs/pressdata/en/reports/78367.pdf.

European Council. (2004). Headline Goal 2010. Retrieved from http://consilium.europa.eu/uedocs/cmsUpload/2010\%20Headline\%20Goal.pdf.

European Council. (2008). Report on the Implementation of the European Security Strategy Providing Security in a Changing World. Brussels, 11 December 2008. Retrieved from www.eu-un.europa.eu/documents/en/081211_EU Security Strategy.pdf.

European Defence Agency. (2006). An Initial Long-Term Vision for European Defence Capability and Capacity Needs. Brussels: Endorsed by EDA's Steering Board. Retrieved from www.eda.europa.eu/webutils/downloadfile. aspx?fileid=106.

Ferrero-Waldner, B. (2008). Die EU-Außenpolitik nach Lissabon. Speech given on 25 January, Vienna. Retrieved from http://ec.europa.eu/commission_barroso/ferrero-waldner/index_de.htm.

Fitoussi, J.-P., \& Laurent, Él. (2009). Europe in 2040: Three Scenarios. Collection OFCE/ANR $\mathrm{n}^{\circ}$ 10. Paris: OFCE/Sciences Po.

Friedman, G. (2011). The Crisis of Europe and European Nationalism. Stratfor Global Intelligence Weekly, 13 September 2011. Retrieved from www.stratfor.com/weekly/20110912-crisis-europe-and-european-nationalism.

Galtung, J. (1973). The European Community: $A$ Superpower in the Making? London: HarperCollins.

Giegerich, B., \& Comolli, V. (Eds.). (2009). FORESEC Deliverable D 4.5 Report on European Security: Trends, Drivers, Threats. Retrieved from www.foresec.eu/wp3_docs/FORESEC_Deliverable_D_4_5.pdf.

Ginsberg, R., \& Smith, M. (2005). Understanding the European Union as a Global Actor: Theory, Practice and Impact. Montreal: $\mathrm{n} / \mathrm{a}$. Retrieved from www. princeton.edu/ smeunier/GinsbergSmith\%20Memo.pdf

Ginsberg, R., \& Smith, M. (2007). Understanding the European Union as a Global Actor: Theory, Practice and Impact. In Sophie Meunier \& Kathleen R. McNamara (Eds.). Making History: 
European Integration and Institutional Change at Fifty. Oxford: Oxford University Press, pp. 267-283.

Hagmann, J. (2011). Fukushima and the Limits of Risk Analysis. Strategic Trends Analysis 104. Zurich: Centre for Security Studies, ETH. Retrieved from http://www.sta.ethz.ch/CSSAnalysis-in-Security-Policy/No.-104-Fukushima-and-the-Limits-of-Risk-Analysis-November2011.

Hammes, T. X. (2007). Fourth Generation Warfare Evolves, Fifth Emerges. Military Review, MayJune 2007, 14-23. Retrieved from http://usacac.army.mil/CAC2/MilitaryReview/Archives/ English/MilitaryReview_20070630_art006.pdf.

Homer-Dixon, T. (1994). Environmental Scarcities and Violent Conflict: Evidence from Cases. International Security 19(1), 5-40. Retrieved from www.library.utoronto.ca/pcs/evidence/evid1.htm and the follow-up web pages.

Institute for the Study of Diplomacy. (2008). America's Role in the World. Washington: Georgetown University, 9 - 17.

Kaldor, M. (1999). New and Old Wars: Organised Violence in a Global Era. Cambridge: Polity Press.

Kerremans, B. (1996). Do Institutions Make a Difference? Non-Institutionalism, NeoInstitutionalism, and the Logic of Common Decision-Making in the European Union. Governance 9(2), 217-240.

Khouri, R. "Mideast power and confusion," International Herald Tribune, 12 October 2011.

Knodt, M., \& Princen, S. (Eds.). (2003). Understanding the European Union's External Relations, ECPR Studies in European Political Science. London: Routledge.

Knudsen, T.B. (1999). Humanitarian Intervention and International Society: Contemporary Manifestations of an Explosive Doctrine, Ph.D. thesis. Aarhus, Denmark: University of Aarhus.

Laursen, Finn (Ed.). (2009). The EU in the Global Political Economy. Brussels: Peter Lang.

Lefebvre, M. (2004). L'europe, puissance par la défense? Défense nationale. Études politiques, stratégiques, militaires, économiques, scientifiques 60(5), pp. 42-55.

Leonard, M. (2011). Four Scenarios for the Reinvention of Europe. Brussels: The European Council on Foreign Relations. Retrieved from http://ecfr.eu/content/entry/four_scenarios_reinvention.

Mahbubani, Kishore (2009). The New Asian Hemisphere: The Irresistible Shift of Global Power to the East. New York, NY: Public Affairs.

Manners, I. (2006). Normative Power Europe Reconsidered: Beyond the Crossroads. Journal of European Public Policy 13(2), 182-199.

Metzger, M., (2005). European Vulnerability to Global Change, a Spatial Explicit and Quantitative Assessment, PhD thesis, Wageningen, The Nederlands: Wageningen University.

Miliband, D. (2007). Speech at the College of Europe, Bruges, 15 November 2007. Retrieved from www.britischebotschaft.de/en/news/items/071115a.htm. 
Missiroli, A. (2010). The New EU 'Foreign Policy' System after Lisbon: A Work in Progress. European Foreign Affairs Review 15, pp. 443-44.

Möcklip D. (2011). Strategic trends 2011, Center for Security Studies, ETH Zurich.

National Intelligence Council. (2000). Global Trends 2015: A Dialogue about the Future with Nongovernment Experts. Retrieved from www.dni.gov/nic/PDF_GIF_global/globaltrend2015.pdf.

National Intelligence Council. (2004). Mapping the Global Future. Washington DC. Retrieved from www.dni.gov/nic/NIC_globaltrend2020.html\#contents.

National Intelligence Council. (2008). Global Trends 2025: A Transformed World, Washington DC, November 2008, pp. 60-99. Retrieved from www.dni.gov/nic/PDF_2025/2025_Global_Trends_Final_Report.pdf.

NATO (2010). Strategic Concept for the Defence and Security of the Members of the North Atlantic Treaty Organisation. Adopted by Heads of State and Government in Lisbon. Art. 32.

Nye, J. S. (2004). Soft Power: The Means to Success in World Politics. New York: PublicAffairs.

Peake, G., Scheve, E., \& Hills, A. (Eds.). (2007). Managing Insecurity. Field Experiences of Security Sector Reform. London: Routledge.

Piris, J.-C. (2011). The Future of Europe. Cambridge: Cambridge University Press.

Rademaker, M. (2009). National Security Strategy of the Netherlands: An Innovative Approach. Information \& Security: An International Journal 23(1), 51-61.

Ratchev, V. (2009). Context Scenarios in Long-Term Defense Planning. Information \& Security: An International Journal 23(1): 62-72.

Renfroe, N.A., \& Smith, J.L. (2011). Threat/Vulnerability Assessments and Risk Analysis. Washington, DC: National Institute for Building Sciences. Retrieved from www.wbdg.org/resources/riskanalysis.php.

RF \& GBN (2010). Scenarios for the Future of Technology and International Development. The Rockefeller Foundation \& Global Business Network. Retrieved from www.rockefellerfoundation.org/news/publications/scenarios-future-technology.

Rhodes, Carolyn (Ed.) (1998). The European Union in the World Community. Boulder, CO: Lynn Rienner.

Ritchey, T. (1998). Fritz Zwicky, Morphologie and Policy Analysis. Paper presented at the 16th EURO Conference on Operational Analysis, Brussels.

Scheipers, S., \& Sicurelli, D. (2007). Normative Power Europe. Journal of Common Market Studies 45(2), pp. 435-457.

Sheehan, M. (2010). The Changing Character of War. In Baylis, J., Smith, S., \& Owens, P. (Eds.), The Globalization of World Politics - An Introduction to International Relations. Oxford University Press, pp. 211-225. Chapter 12 can be retrieved from www.oup.com/uk/orc/bin/ 9780199297771/baylis_ch12.pdf.

Sjöstedt, G. (1977). The External Role of the European Community. Farnborough: Saxon House. 
Smith, M. (2006). The EU as an International Actor. In Jeremy Richardson (Ed.), European Union. Power and Policy Making, 3rd edition, Abingdon: Routledge, pp. 289-309.

Solana, Javier. (2001). 'L'europe-puissance' - Interview to Politique internationale 92, pp. 213-248.

Spero, J. (1985). The Politics of International Economic Relations. London: John Allen \& Unwin.

Strategic Trends Programme. (2007), The DCDC Global Strategic Trends Programme 2007-2036 London: Development, Concepts and Doctrine Centre.

Strategic Trends Programme. (2010). Global Strategic Trends - out to 2040, Fourth edition. London: Development, Concepts and Doctrine Centre. Retrieved from www.mod.uk/NR/rdonlyres/38651ACB-D9A9-4494-98AA1C86433BB673/0/gst4_update9_Feb10.pdf.

Stedman, S., Jones, B., \& Pascual, C. (2008). Managing Global Insecurity: A Plan for Action. Washington, D.C.: The Brookings Institution.

Schwartz, P. (1991). The Art of the Long View: Planning for the Future in an Uncertain World. Ne Your, NY: Doubleday.

The United States Commission on National Security/21st Century (1999). New World Coming: American Security in the 21st Century, Study Addendum. Retrieved from www.au.af.mil/au/awc/awcgate/nssg/addendum.pdf.

Tonra, B., \& Christiansen, T. (Eds.). (2004). Rethinking European Union Foreign Policy. Manchester: Edward Elgar.

Van Creveld, M. (1991). The Transformation of War. New York: Free Press.

Watson, A. (1992). The Evolution of International Society: A Comparative Historical Analysis, with Introduction by Barry Buzan and Richard Little. London: Routledge.

Wessels, W. (2005). Theoretical Perspectives. CFSP beyond the Supranational and Intergovernmental Dichotomy. In Dieter Mahnke, Alicia Ambos and Christopher Reynolds (Eds.). European Foreign Policy. From Rhetoric to Reality? Brussels: College of Europe Studies, pp. 61-96.

Wessels, W., \& Bopp, F. (2008). The Institutional Architecture of CFSP after the Lisbon Treaty Constitutional Breakthrough or Challenges Ahead? Brussels: Centre for European Policy Studies.

Wessels, W., \& Regelsberger, E. (2005). The Evolution of the Common Foreign and Security Policy. A case of an Imperfect Ratchet Fusion. In Amy Verdun and Osvaldo Croci (eds), The European Union in the Wake of Eastern Enlargement. Institutional and Policy-making Challenges, Manchester/New York: Manchester University Press, pp. 91-116.

White, Brian (2001). Understanding European Foreign Policy. London: Palgrave Macmillan.

Whitman, R.G. (1998). From Civilian Power to Superpower? The International Identity of the European Union. London: Palgrave Macmillan.

World Energy Council. (2008). Europe's Vulnerability to Energy Crises: Executive Summary. London. Retrieved from www.worldenergy.org/documents/vulnerabilityesfinal_1.pdf. 